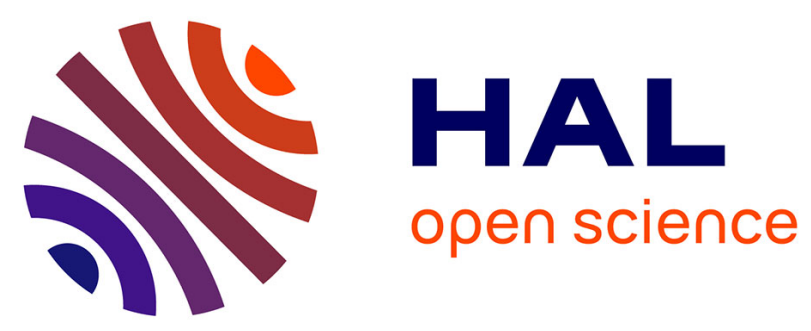

\title{
Controlling factors for differential subsidence in the Sonoma Foreland Basin (Early Triassic, western USA)
}

Gwénaël Caravaca, Arnaud Brayard, Emmanuelle Vennin, Michel Guiraud, Laetitia Le Pourhiet, Anne-Sabine Grosjean, Christophe Thomazo, Nicolas Olivier, Emmanuel Fara, Gilles Escarguel, et al.

\section{To cite this version:}

Gwénaël Caravaca, Arnaud Brayard, Emmanuelle Vennin, Michel Guiraud, Laetitia Le Pourhiet, et al.. Controlling factors for differential subsidence in the Sonoma Foreland Basin (Early Triassic, western USA). Geological Magazine, 2018, 155 (6), pp.1305 - 1329. 10.1017/S0016756817000164 . hal-01848947

\section{HAL Id: hal-01848947 \\ https://hal.science/hal-01848947}

Submitted on 28 Jan 2022

HAL is a multi-disciplinary open access archive for the deposit and dissemination of scientific research documents, whether they are published or not. The documents may come from teaching and research institutions in France or abroad, or from public or private research centers.
L'archive ouverte pluridisciplinaire HAL, est destinée au dépôt et à la diffusion de documents scientifiques de niveau recherche, publiés ou non, émanant des établissements d'enseignement et de recherche français ou étrangers, des laboratoires publics ou privés. 


\section{Controlling factors for differential subsidence in the Sonoma Foreland Basin (Early Triassic, western USA)}

4 Published in Geological Magazine 155, 1305 - 1329

6 Gwénaël Caravaca ${ }^{1}$, Arnaud Brayard ${ }^{1}$, Emmanuelle Vennin ${ }^{1}$, Michel Guiraud ${ }^{1}$, Laetitia Le Pourhiet ${ }^{2}$,

7 Anne-Sabine Grosjean ${ }^{1}$, Christophe Thomazo ${ }^{1}$, Nicolas Olivier ${ }^{3}$, Emmanuel Fara $^{1}$, Gilles Escarguel ${ }^{4}$,

$8 \quad$ Kevin G. Bylund ${ }^{5}$, James F. Jenks ${ }^{6}$, Daniel A. Stephen ${ }^{7}$.

$9{ }^{1}$ Biogéosciences UMR6282, CNRS, Univ. Bourgogne Franche-Comté, 21000 Dijon, France

${ }^{2}$ Sorbonne Universités, UPMC Univ Paris 06, CNRS, Institut des Sciences de la Terre de Paris (iSTeP), 4

11 place Jussieu 75005 Paris, France

${ }^{3}$ Laboratoire Magmas et Volcans, CNRS, IRD, OPGC, Université Blaise Pascal, 63038 Clermont

13 Ferrand, France

${ }^{4}$ UMR 5023 LEHNA, Université Lyon 1, 69622 Villeurbanne Cedex, France

${ }^{5} 140$ South 700 East, Spanish Fork, Utah 84660, USA

$16{ }^{6} 1134$ Johnson Ridge Lane, West Jordan, Utah 84084, USA

$17{ }^{7}$ Department of Earth Science, Utah Valley University, Orem, Utah 84058, USA

18 Contact details for corresponding author: Phone: +33.3.80.39.62.54. E-mail: gwenael.caravaca@u-

19 bourgogne.fr 


\section{Abstract -}

Sediments deposited from the Permian-Triassic boundary $(\sim 252<5>\mathrm{Ma})$ until the end-Smithian (Early Triassic; c. 250.7<5>Ma) in the Sonoma Foreland Basin show marked thickness variations between its southern (up to $c .250<5>\mathrm{m}$ thick) and northern (up to $c .550<5>\mathrm{m}$ thick) parts. This basin formed as a flexural response to the emplacement of the Golconda Allochthon during the Sonoma orogeny. Using a high-resolution backstripping approach, a numerical model and sediment thickness to obtain a quantitative subsidence analysis, we discuss the controlling factor(s) responsible for spatial variations in thickness. We show that sedimentary overload is not sufficient to explain the significant discrepancy observed in the sedimentary record of the basin. We argue that the inherited rheological properties of the basement terranes and spatial heterogeneity of the allochthon are of paramount importance in controlling the subsidence and thickness spatial distribution across the Sonoma Foreland Basin.

Keywords: Early Triassic, Sonoma orogeny, foreland basins, lithospheric strength, subsidence.

\section{Introduction}

The Sonoma Foreland Basin (SFB, western USA; Fig. 1a) provides an excellent Early Triassic fossil and sedimentary record (Hofmann et al. 2014; Brayard et al. 2015; Thomazo et al. 2016). This N-S-trending foreland system (sensu DeCelles \& Giles, 1996) was located on the western Pangea margin and results from the emplacement of the Golconda Allochthon (GA) during the Sonoma orogeny around the Permian-Triassic boundary (Fig. 1; Burchfiel \& Davis, 1975; Speed \& Silberling, 1989; Ingersoll, 2008; Dickinson, 2013). Nevertheless, despite numerous studies, the geometry and the palaeogeography of this basin remain poorly constrained. The SFB covered a large area including present-day eastern Nevada, Utah, Idaho and parts of Wyoming (Marzolf, 1993; Dickinson, 2006, 2013; Ingersoll, 2008).

Foreland sedimentary basins are generally considered as passive systems resulting from the flexural subsidence of the elastic lithosphere in response to crustal thickening and sediment loading (e.g. DeCelles \& Giles, 1996; Allen \& Allen, 2005). If the flexural isostatic model is a reasonable first-order explanation for the overall shape of foreland basins, sediment thickness variations and peculiar stratigraphic successions involve a differential local subsidence. In order to decipher such potential mechanisms at the origin of the SFB structuring and sedimentary record variations, we use a multidisciplinary approach. We perform a subsidence analysis of the basin within a high-resolution biostratigraphically controlled timeframe from the Permian-Triassic unconformity (PTU) up until late Smithian time (a c. $1.3<5>$ Ma long interval; the Smithian is the third substage of the Early Triassic). This allows us to characterize the basin infill in relation to the emplacement of the Golconda 
Allochthon during the Sonoma orogeny. We also provide new evidence indicating that the studied area is a foreland basin. Using a complementary backstripping approach and numerical models we discuss the main factors controlling the subsidence variations observed in the SFB, including the impact of lithospheric and rheological features, on basement partitioning and sedimentation.

\section{Geological setting}

\section{2.a. Brief geological history of the study area}

The Sonoma Foreland Basin lies within a region of the North American continent showing a very long and complex tectonosedimentary history starting during Proterozoic time and still active today (e.g. Dickinson, 2013). The first documented structuring of the region dates back to the Palaeoproterozoic period when Mojave and Yavapai terranes were emplaced against the Archean Wyoming craton (Fig. 1b; Whitmeyer \& Karlstrom, 2007, fig. 9; Lund et al. 2015). This event generated multiple crustal fault zones along which later reactivations were possible with deformational episodes (Oldow et al. 1989; Dickerson, 2003). At least two rifting events took place in this region during subsequent Proterozoic times (Burchfiel \& Davis, 1975; Oldow et al. 1989), the most recent being during Neoproterozoic time $($ c. $770<5>\mathrm{Ma})$ and linked to the fragmentation of the supercontinent Rodinia (Fig. 1b; Dickinson, 2006). The long period of tectonic quiescence following the formation of this passive margin lasted until Late Devonian time (c. $380<5>\mathrm{Ma})$ and corresponds to the deposition of a thick sedimentary prism formerly known as the ‘Cordilleran Miogeocline’ (Clark, 1957; Paull \& Paull, 1991; Dickinson, 2006, 2013).

Starting during Late Devonian time and lasting until late Early Carboniferous time, the Antler orogeny marks the beginning of a period of nearly continuous structural events that are still active today (Fig. 1b). The Antler orogeny was caused by the convergence and accretion of exotic island-arcs against the western margin of the North American Plate. This orogeny is characterized by the emplacement of a large obducted accretionary prism located in Central Nevada today (i.e. Roberts Mountains Thrust, Fig. 1c; Burchfiel \& Davis, 1975; Speed \& Sleep, 1982; Speed \& Silberling, 1989; Burchfiel \& Royden, 1991). The Roberts Mountains Allochthon led to the formation of the N-S-trending westwards-dipping Antler Foreland 
Basin (Speed \& Sleep, 1982; Burchfiel \& Royden, 1991; Blakey, 2008; Ingersoll, 2008; Dickinson, 2004, 2006, 2013).

Soon after the Antler orogeny the Ancestral Rocky Mountains (ARM) orogeny occurred on the eastern part of the region (Fig. 1c), ranging over Early Carboniferous to early-middle Permian time (c. 350-270<5>Ma; Fig. 1b). This mountain-building event resulted from a succession of crustal uplifts because of important long-range intracratonic deformations. There, transtensional and transpressional constraints occurred along with lithospheric buckling as a response to the Laurentia-Gondwana continental collision (Kluth \& Coney, 1981; Ye et al. 1996; Geslin, 1998; Dickerson, 2003; Dickinson, 2006, 2013; Blakey, 2008). The resulting chain probably showed a marked topographic relief, some of which could have persisted until Early Triassic time (Kluth \& Coney, 1981; Blakey, 2008). Most of these crustal uplifts were emplaced according to lithospheric weaknesses inherited from the Proterozoic structural events (Kluth \& Coney, 1981; Dickerson, 2003).

Many sedimentary basins formed during the Carboniferous-Permian interval (Dickerson, 2003). For instance, the Permian Oquirrh Basin (Fig. 1c) probably resulted from the complex interplay between intracratonic deformations to the east and the reactivation of Antler faults to the west (Geslin 1998: fig. 12; Trexler \& Nitchman, 1990; Dickerson, 2003; Blakey, 2008). This highly subsiding basin recorded up to $6<5>\mathrm{km}$ of marine strata (Walker, 1985; Yonkee \& Weil, 2015).

Similarly to the Antler orogeny, the Sonoma orogeny is the result of the eastwards migration and accretion of exotic island-arc systems belonging to the Sonomia microplate onto the North American Plate around the Permian-Triassic boundary (Burchfiel \& Davis, 1975; Speed \& Silberling, 1989; Dickinson, 2006, 2013; Blakey, 2008; Ingersoll, 2008). The Sonoma orogeny is characterized by the thrusting of an accretionary prism above continental crust, known as the Golconda Allochthon, and emplaced in the same area as the older Roberts Mountains Allochthon (Fig. 1c). The Golconda Allochthon is thought to have initiated the formation of a foreland basin - the Sonoma Foreland Basin (Dickinson, 2006, 2013; Blakey, 2008; Ingersoll, 2008) - which recorded sediments deposited during Early Triassic time. However, field evidence pointing towards the location and extension of the Golconda Allochthon is restricted to only a few remnants (e.g. 'Koipato volcanics') near the southern 
112 part of the basin, which are presently located in Central Nevada (Fig. 1c; Snyder \&

113 Brueckner, 1983; Walker, 1985; Schweickert \& Lahren, 1987; Oldow et al. 1989; Dickinson, 114 2006, 2013; Blakey, 2008; Ingersoll, 2008). Remnants of the Golconda Allochthon, if any, 115 are yet to be found in the northern part of the basin, especially in Idaho (Schweickert \& 116 Lahren, 1987; Oldow et al. 1989). This allochthon is sealed in present-day Nevada by the 117 rhyolitic Koipato Formation volcanism, presumably emplaced by the end of the Sonoma 118 orogeny (Vetz, 2011). A minimum age of Anisian (Middle Triassic) can be given to this 119 volcanic formation using geochronology (Vetz, 2011) and due to the occurrence of Anisian ammonites in the unconformably overlying sedimentary series (Nichols \& Silberling, 1977; Bucher, 1988; Vetz, 2011). The potential presence of older ammonoid faunas is not to be discarded.

The following Sevier orogeny is of Early Cretaceous - Eocene age (c. $140-50<5>\mathrm{Ma}$; Fig. 1b) and it originated from the subduction of the Farallon Plate under the North American continental plate (Burchfiel \& Davis, 1975; Dickinson, 2006, 2013). E-W-directed compressive constraints resulted in the formation of a large Sevier thrust-and-fold belt which is still present today and constitutes the eastern border of the Great Basin (Fig. 1c; Dickinson, 2006, 2013; Yonkee \& Weil, 2010; Yonkee et al. 2014). This thrust-and-fold belt is however not homogeneous along its $\mathrm{N}-\mathrm{S}$-trending front, and displays two convex-to-the-foreland 'salients' (Fig. 2) with varying estimated tectonic shortening and eastwards displacement of terrains reaching up to $140<5>\mathrm{km}$ (DeCelles \& Coogan, 2006; Schelling et al. 2007; Dickinson, 2006, 2013; Yonkee \& Weil, 2010, 2015; Yonkee et al. 2014). These Wyoming and Central Utah salients are separated by a conspicuous recess formed by a lateral ramp and located west of the Uinta Mountains (Figs 1c, 2). Its formation results from inherited features of the basement (see Section 4.c; e.g. Lawton, Boyer \& Schmitt, 1994; Mukul \& Mitra, 1998; Paulsen \& Marshak, 1999; Wilkerson, Apotria \& Farid, 2002).

Also during Early Cretaceous - Eocene time, the eastern Laramide orogeny reactivated basal crustal uplifts set during the Ancestral Rocky Mountains orogeny. This led to the formation of the modern-day Rocky Mountains which overlapped older structures in the Colorado Plateau (Fig. 1b, c; Oldow et al. 1989; Ye et al. 1996; Dickinson, pers. comm. 2015). 
Finally, the Basin and Range extension of the entire region started during Neogene time (c. 20<5>Ma; Fig. 1b) and is still active today (Oldow et al. 1989; DeCelles \& Coogan, 2006; Dickinson, 2002, 2006, 2013). This extension is the result of internal forces (Kreemer \& Hammond, 2007) that generated transtensional stresses and pure shear (Parsons, Thompson \& Sleep, 1994; Gans \& Bohrson, 1998; Dickinson, 2002, 2006). However, the origin of these extensional constraints is still being discussed. Several possible mechanisms have been proposed, including: (1) a mantellic 'wide rift-like' process with ascent and underplating of mantellic material leading to thermal lamination of the lithosphere (Lachenbruch \& Morgan, 1990; Parsons, Thompson \& Sleep, 1994, Gans \& Bohrson, 1998); or (2) a mechanical origin with the extension occurring in a late orogenic context, due to the instability and gravity collapse of the thickened lithospheric crust present in Nevada and westernmost Utah (Fletcher \& Hallet 1983; Malavieille, 1993; Zandt, Myers \& Wallace, 1995). Nevertheless, the easternmost borders of the basin (e.g. Colorado Plateau or Uinta Mountains) are not affected by these displacements (Fig. 1c; Dickinson, 2006, 2013). It is also worth noting that this extension reactivates in inversion some of the thrust faults created during the Sevier orogeny (Coney, 1987; Dickinson, 2006, 2013).

\section{2.b. Sedimentary record of the Sonoma Foreland Basin}

Here we focus on the Early Triassic sedimentary record of the Sonoma Foreland Basin (Figs 3a, 4). The stratigraphic succession displays marked spatial differences in thickness and in dominant lithologies (Fig. 4). The sedimentary record is considered as almost continuous throughout the basin, with local erosion surfaces being under the temporal resolution of ammonoid biozones for this Early Triassic interval (e.g. Olivier et al. 2014, 2016; Vennin et al. 2015). In its southern part (Figs 3a, 4), the basin is mainly filled with transitional continental to marine coarse sandstones to conglomerates known as 'red beds' of the Moenkopi Group (Fig. 5a-c, e; sensu Lucas, Krainer \& Milner, 2007; Brayard et al. 2013). At the top of the Moenkopi Group, metric-scale beds of intertidal microbial limestones can be observed (Figs 3a, 4, 5e; Brayard et al. 2013; Vennin et al. 2015; Olivier et al. 2016). The upper part of the sedimentary pile is characterized by open-marine bioclastic limestones (locally shales) of the Thaynes Group (Figs 3a, 4, 5d, f; sensu Lucas, Krainer \& Milner, 2007), marking the maximum flooding of the Smithian third-order transgression (Embry, 1997; Vennin et al. 2015). This flooding event is characterized by the presence of the 
ammonoid genus Anasibirites (Figs 3a, 4; Lucas, Krainer \& Milner, 2007; Brayard et al. 2013; Jattiot et al. 2015, in press). In the northern part of the basin (Figs 3a, 4) the sedimentary record differs at its base by the presence of the Dinwoody and Woodside formations, characterized by fine marine siltstones (Figs 3a, 4, 5g; Kummel, 1954, 1957; Sadler, 1981; Paull \& Paull, 1991). Above these formations, the sedimentary record resembles that observed in the southern part and corresponds to the open-marine bioclastic limestones and shales of the Thaynes Group (Figs 3a, 4, 5d, h). A basin-scale synthetic facies analysis with associated depositional environments and estimations of the palaeobathymetries can be found in online Supplementary Table S1 (available at http://journals.cambridge.org/geo).

\section{Dataset and methods}

\section{3.a. Dataset}

We compiled a comprehensive sedimentary and biostratigraphic dataset for the Early Triassic outcrops in the Sonoma Foreland Basin, including previously published works (e.g. Kummel, 1954, 1957; Paull \& Paull, 1991; Goodspeed \& Lucas, 2007; Heckert et al. 2015) together with new field data (Fig. 3b). We selected 43 biostratigraphically correlated sections documenting different parts of the basin in order to estimate the thickness (at the metre scale) of the sedimentary deposits (GPS coordinates and main characteristics of each section are provided in online Supplementary Table S2). The 43 studied sections correspond to the Early Triassic interval. The base of this interval is defined by a major regional PTU (Brayard et al. 2013). Its upper end is determined by the Anasibirites beds or the uppermost part of the Owenites beds as a surrogate, which are the main biostratigraphic markers of the endSmithian (Figs 3a, 4; Brayard et al. 2013; Jattiot et al. 2015). Eleven sections were delimited using a high-resolution ammonoid zonation (e.g. sections in Fig. 4; Brayard et al. 2013). We conservatively used only minimum thickness values for the 32 sections taken from the literature because they are not always based on homogeneous sedimentary and biostratigraphical data (online Supplementary Table S2). For completeness of the subsidence analysis, we included when possible thickness data available for the lower part of the Spathian (fourth substage of the Early Triassic), the Columbites beds marking in this case the end of the studied interval (Fig. 3a). 


\section{3.b.1. Palinspastic reconstructions using retrodeformations}

Post-Triassic times in the Sonoma Foreland Basin are characterized by important tectonic compressive and later extensive deformations. These successive deformations are mostly represented in the basin by the complex and heterogeneous Sevier thrust-and-fold belt. The palaeogeographic configuration of the Sonoma Foreland Basin was therefore different compared to the modern configuration. In order to resolve this issue, we performed a palinspastic reconstruction to estimate the Early Triassic palaeogeography of this basin.

Retrodeformations of observed structural features affecting the Triassic series were applied to several regional cross-sections using literature data (e.g. DeCelles \& Coogan, 2006; Yonkee \& Weil, 2010; Fig. 6). This method consists of the horizontalization of a selected layer (here the Triassic series) by virtually inverting all the structural features observed in the section between a fixed reference point named the 'pin line' and a mobile reference point named the 'loose line' (Fig. 6; see Groshong, 2006 for details). In the two regional cross-sections of the Sevier thrust-and-fold belt illustrated in Figure 6, most structural features are thrust complexes; horizontalization therefore mainly consists of retrodeformation of the displacements along thrust planes. Finally, balanced cross-sections represent a good approximation of the geomorphological setting by the time of deposition. Based on this method, the direction and value of the estimated tectonic transport (ETT) underwent by the terrains can also be calculated (e.g. $c .140<5>\mathrm{km}$ and $c .60<5>\mathrm{km}$ for the cross-sections a and b in Fig. 6, respectively).

Due to the complex nature of the Sevier thrust-and-fold belt resulting from the inherited structure and thickness pattern of the pre-deformation basins (Paulsen \& Marshak, 1999), and also the westwards focalization of the subsequent Basin and Range extension, ETT was spatially heterogeneous between Wyoming and Central Utah salients (Mukul \& Mitra, 1998; DeCelles \& Coogan, 2006; Schelling et al. 2007; Yonkee \& Weil, 2010; Yonkee et al. 2014). We therefore defined seven sectors within our study area (sectors 1-7 in Fig. 7). These sectors were delimited based on similar ETT values (Table 1; Fig. 7). These values were determined from data available in the literature (references in Table 1) and checked with the 
232 retrodeformation of regional cross-sections taken from geological maps (cross-sections in 233 Fig. 6).

\section{3.b.2. Subsidence analysis and backstripping}

Subsidence analysis quantifies the vertical movements underwent by a given sedimentary depositional surface through a graphic representation, by tracking the subsidence and uplift history of said surface (Van Hinte, 1978). This history is reconstructed based on sedimentary thickness, lithology, palaeo-sea level, palaeobathymetry and age data. This analysis also accounts for the mechanical compaction underwent by the sediments. The resulting curve provides a view of the total subsidence history for a given stratigraphic column (Van Hinte, 1978; Allen \& Allen, 2005). Steckler \& Watts (1978) showed that the local isostatic effect exerted by the sedimentary load can be removed. This 'backstripping' method can therefore help to characterize the tectonic subsidence only, as if the basin has been filled by air only and not by water and/or sediment during its history (Steckler \& Watts, 1978; Xie \& Heller, 2009). Backstripping is also used to restore the initial thickness of a sedimentary column (Angevine, Heller \& Paola, 1990; Allen \& Allen, 2005). Lithological compositions and palaeobathymetries have been checked using facies analysis (online Supplementary Table S1) or literature data (see analysed sections in Fig. 3b and online Supplementary Table S2). Porosity was quantified by comparison with experimental data (e.g. Van Hinte, 1978; Sclater \& Christie, 1980) and represents an important proxy for compaction analysis. Additionally, Chevalier et al. (2003) and Lachkar et al. (2009) showed that a highly resolved biostratigraphic control is useful to define and quantify variations in subsidence at a fine spatio-temporal scale as it yields accurate subsidence rates. For the Early Triassic Sonoma Foreland Basin, the high-resolution ammonoid zonation by Brayard et al. (2013) serves as the main timeframe. Complementary absolute time lines were obtained from radiometric ages published from coeval beds in South China (Galfetti et al. 2007; Burgess, Bowring \& Shen, 2014), whereas the duration of the studied intervals was interpolated from ammonoid biozone duration (after Brühwiler et al. 2010 and Ware et al. 2015). Palaeo-sea level curve is based on data from Haq, Hardenbol \& Vail (1988), providing a quantitative representation of the reconstructed Early Triassic sea level. 
We chose to not use the flexural backstripping method (Allen \& Allen, 2005) due to the lack of appropriate data needed for such model (e.g. flexural rigidity data, regional distribution of the sedimentary load). Instead, we calculated the total and tectonic subsidence curves using the one-dimensional (1D) local isostatic approach of Steckler \& Watts (1978). In addition, this method emphasizes the tectonic subsidence as 'a way of normalizing subsidence in different basins that have undergone very different sedimentation histories' (Xie \& Heller, 2009). Our results for the tectonic subsidence history in the SFB can therefore be compared to the compilation of Xie \& Heller (2009). Subsidence analyses were performed on four sections (Fig. 3b) using the OSXBackstrip software performing 1D Airy backstripping (after Watts, 2001; Allen \& Allen, 2005; available at: http://www.ux.uis.no/ nestor/work/programs.html). These sections were selected for their completeness (a complete and continuous sedimentary succession is reported from the PTU to at least lower Spathian stratigraphy), for the presence of biostratigraphic markers (ammonoid beds) and for their repartition within the SFB (representative of both the northern and southern areas). A complete set of initial parameters and detailed results of the subsidence analysis for each of the four sections are reported in online Supplementary Material S1.

This analysis bears limitations as some errors may arise from uncertainties around the data used for the subsidence analysis (Chevalier et al. 2003; Xie \& Heller, 2009): (1) accuracy of the measurement and report of the sedimentary thickness; (2) backstripping calculation; (3) palaeo-bathymetry estimations; and (4) age control. Regarding the accuracy of the sediment thickness, all selected sections have been measured at a centimetric scale. Errors on measurements are therefore rather low, i.e. $\pm 2<2>\%$ of the total thickness. In the backstripping analysis, variables used for the calculation of the burial compaction are: thickness; the initial porosity of the sediment; and the lithological constant of corresponding lithologies. The latter two parameters are determined by comparison with experimental data (e.g. Van Hinte, 1978; Sclater \& Christie, 1980). Error on sediment decompaction is therefore estimated to be low $(c . \pm 5<2>\%$ ). Palaeobathymetry is hard to determine because of the paucity of discriminating indicators. We hypothesize that errors on depth estimations are about $\pm 10<2>\%$. For age control, we used a compilation of biostratigraphic and 
291

radiochronological data, leading to a detailed timeframe with a maximum error of around $60<5>$ ka (Brühwiler et al. 2010).

\section{3.b.3. Spatial distribution of sedimentary thickness}

PTU-Smithian sedimentary thicknesses and their respective location within the SFB were integrated in Global Mapper v.16.2.3 GIS software (available at http://www.bluemarblegeo.com/products/global-mapper.php) to generate an isopach map by creating a 3D triangulated grid projection of thicknesses (online Supplementary Figure S1).

\section{3.b.4. Lithospheric heterogeneity of the basement}

To explore the nature of the SFB basement, a terrane map was constructed using previous published maps by Yonkee et al. (2014), Yonkee \& Weil (2015) and Lund et al. (2015). In addition, we analysed several types of geophysical data: a raw regional Bouguer gravity anomaly map (Kucks, 1999); an aeromagnetic anomaly map from Bankey et al. (2002); and literature data (e.g. Gilbert, Velasco \& Zandt, 2007). We also used published $\mathrm{U} / \mathrm{Pb}$ radiochronological data to assess an age for each basement terrane defined in the basin (Foster et al. 2006; Fan et al. 2011; Mueller et al. 2011; Nelson, Hart \& Frost, 2011; Strickland, Miller \& Wooden, 2011). It is worth noting that Precambrian crystalline basements, lying under detachments and décollements responsible for nucleation of thrusting, are not affected by these 'thin-skin' thrust-induced displacements (DeCelles \& Coogan, 2006; Schelling et al. 2007; Yonkee \& Weil, 2010).

\section{3.b.5. Numerical model}

The flexural response of the SFB basement has been simulated using a $2 \mathrm{D}$ plane stress flexural model solved with a finite element method code written in Matlab ${ }^{\circledR}$. This approach has been successfully used to model lithospheric deformation due to topographic and mantle loads (Le Pourhiet \& Saleeby, 2013) and ice loads (Moreau et al. 2015). First, a model of the basin is made using field-based and literature data to characterize and quantify the flexural response of the modelled SFB basement. Three additional models are then proposed to test different scenarios regarding possible mechanisms controlling the flexure of the SFB basement. 


\section{Results}

We first reconstructed the SFB palaeogeography and used lithological and stratigraphical analyses to constrain the spatial distribution of the sedimentary record across the basin. This approach provides estimations of subsidence rates in the SFB. Secondly, we identified and characterized the terranes that compose the SFB basement using geophysical and cartographic data, as well as previously published ages. We then reconstructed the morphology of the Golconda Allochthon in relation to the heritage of the basin. Finally, a 2D model is proposed to quantify the flexural behaviour of the basin.

\section{4.a. Lithological and stratigraphical analyses}

Previous palaeogeographic reconstructions of the SFB did not take tectonic events and the ensuing displacements into account (e.g. Paull \& Paull, 1993). The palinspastic map of the basin with the initial locations of the studied sections is shown on Figure 7. For the first time post-Triassic displacements were accounted for, including: (1) the Sevier orogeny (Cretaceous-Eocene) and the associated regional shortening due to the setting of a thrust-andfold belt (e.g. Yonkee \& Weil, 2010); and (2) the later Neogene - present-day extension linked to the Basin and Range province (e.g. Yonkee et al. 2014).

Based on the palinspastic map, we constructed a palaeogeographic isopach map of the SFB (Fig. 8). The isopach map shows that the distribution of the sedimentary thickness for the PTU-Smithian interval is heterogeneous within the basin, showing a thicker succession in the northern than in the southern part. In the southern part, the thickness gradually varies along a roughly NW-SE-aligned transect, showing low thicknesses over a large surface (c. $500<5>\mathrm{km}$ from east to west). The thickness ranges from a few tenths of metres in south and SE Utah, up to $250<5>\mathrm{m}$ around Salt Lake City. The westernmost area (NE Nevada) is also characterized by low thicknesses $(<100<5>$ m thick). Conversely, the northern part of the basin exhibits a marked transition with thickness values broadly increasing from east to west. The easternmost area of the northern part (west Wyoming) shows sedimentary thicknesses similar to that of the southern part $(<300<5>$ m thick; Fig. 8). The west-central area records the thickest succession of the SFB (up to $c .550<5>\mathrm{m}$ thick), and is centred on present-day south-central Idaho. The westernmost area (west-central Idaho) shows similar thicknesses (up to $c .300<5>$ m thick; Fig. 8). 
The subsidence analysis (Fig. 9) also shows a clear distinction between the northern and southern parts of the basin. Confusion Range (CR, Fig. 9a) and Pahvant Range (PR, Fig. 9b) sections exhibit relatively low subsidence curves during the studied interval, whereas Sheep Creek (SC, Fig. 9c) and Hot Springs (HS, Fig. 9d) sections show a high subsidence profile. The total and tectonic subsidence curves are similar and the tectonic subsidence is here a major component of the total subsidence, accounting for at least two-thirds of the total subsidence, if not more (e.g. in CR, Fig. 9a).

When looking at the dominant lithologies (Fig. 9e), the sections from the southern part of the basin display a sedimentary succession dominated by coarse conglomerates and sandstones and microbial limestones of the Moenkopi Group and the limestones/shales of the Thaynes Group (Figs 3, 4, 9e), while the total subsidence is low. By contrast, the sections from the northern part of the SFB are dominated by fine siltstones (Figs 3, 4, 9e) with an important subsidence.

Finally, the tectonic subsidence appears as a critical diagnostic feature for the basin (Fig. 9f). A marked difference exists between mean tectonic subsidence rates in the southern and northern parts of the basin (c. $100<5>\mathrm{m} \mathrm{Ma}^{-1}$ v. c. $500<5>\mathrm{m} \mathrm{Ma}^{-1}$, respectively). The southern sections show a low-rate tectonic subsidence (50-200<5>m Ma ${ }^{-1}$; Fig. 9e). Nevertheless, a marked increase in subsidence rate is recorded during early Spathian time for these sections (150-600<5>m Ma ${ }^{-1}$; Fig. 9e). Conversely, the northern sections show a higher rate of tectonic subsidence during the PTU-Smithian interval $\left(450-650<5>\mathrm{m} \mathrm{Ma}^{-1}\right.$; Fig. 9e), whereas early Spathian time is characterized by a decrease in subsidence rate (100$250<5>\mathrm{m} \mathrm{Ma}^{-1}$; Fig. 9e).

\section{4.b. Basement characterization}

On the gravimetric anomaly map shown on Figure 10a, black lines outline the geophysical features that may represent traces of crustal/lithospheric faults or heterogeneities in the basement (Lowrie, 2007). The lowest Bouguer anomaly values $(<150<5>\mathrm{mGal}$, Fig. 10a) suggest the presence of a thick crust, whereas moderate negative anomalies (between -65 and $-135<5>\mathrm{mGal}$; white outlines) point towards a thinner crust and/or the presence of lower-crustal high-density bodies (e.g. Gilbert, Velasco \& Zandt, 2007; Lowrie, 2007). The Snake River Plain (SRP in Fig. 10a) is a Yellowstone hotspot track-related 
basaltic province. This young (of Neogene age) structure influences neither the geometry nor the properties of the basement (Dickinson, 2013). The Farmington Anomaly (FA on Fig. 10a), located in the centre of the study area, may result from the presence of lowercrustal high-density mafic and/or ultramafic material emplaced during a thermal event dated at c. $1.64<5>\mathrm{Ga}$ (Mueller et al. 2011). Alternatively, it can have originated from a more recent thermal event and/or the presence of a thin lithospheric crust (e.g. Gilbert, Velasco \& Zandt, 2007; Lowrie, 2007). Remnants of an important thermal metamorphism including partial melting (c. 1.67<5>Ga) can also be observed in this area (red dots in Fig. 10c; Mueller et al. 2011). The Southern Anomaly (SA on Fig. 10a) is poorly documented and may result from variations in the crustal thickness of the terrane (e.g. Gilbert, Velasco \& Zandt, 2007; Lowrie, 2007), possibly linked to the Ancestral Rocky Mountains orogeny or to the more recent Laramide orogeny and the building of the Rocky Mountains (Ye et al. 1996; Dickerson, 2003).

The aeromagnetic anomaly map presented in Figure $10 \mathrm{~b}$ discriminates areas of contrasted magnetic signatures (separated by black lines on Fig. 10b). These disturbances in magnetic field are attributed to differences in the nature of the rocks composing the basement (Turner, Rasson \& Reeves, 2007). We do not attempt to identify the exact nature of these rocks here; rather, we use these contrasted anomalies to characterize differences of rock types that compose the basement (Purucker \& Whaler, 2007; Lund et al. 2015). As on the Bouguer gravity anomaly map, the presence of the Snake River Plane hotspot-track (SRP in Fig. 10a, b) is obvious on the aeromagnetic anomaly map. It features a strong positive magnetic anomaly signal $(>150<5>$ nT, Fig. 10b). The Southern magnetic Zone (SZ on Fig. 10b) can be distinguished on the southern part of the studied area by contrasted anomalies with a wide range of variations (from $c .-200<5>\mathrm{nT}$ up to $c .400<5>\mathrm{nT}$ ). The Central magnetic Zone (CZ on Fig. 10b) occupies the central third of the map. It is characterized by generally neutral to (strongly) positive anomalies (from $c$. $-10<5>\mathrm{nT}$ to $c .60<5>\mathrm{nT}$, locally up to $>150<5>\mathrm{nT}$ ). In the northeastern quarter of the studied area, the North-Eastern magnetic Zone (NEZ on Fig. 10b) is characterized by generally negative anomalies (between $c$. $-80<5>\mathrm{nT}$ and $c$. $10<5>\mathrm{nT})$. Some areas with strong positive anomalies $(>150<5>\mathrm{nT})$ are also observed, whose shape and extension are very similar in the Bouguer gravity anomaly map (Fig. 10a). Finally, a small Northern magnetic Zone (NZ on Fig. 10b) is visible north to the SRP and 
west to the NZ. It shows contrasting anomalies, but with a less important range of variation than the SRP and less strongly positive values (from $c$. $-60<5>\mathrm{nT}$ to $c .150<5>\mathrm{nT}$ only).

Figure 10c synthesizes the location and the different $\mathrm{U} / \mathrm{Pb}$ radiochronological ages for the basement (Foster et al. 2006; Fan et al. 2011; Mueller et al. 2011; Nelson, Hart \& Frost, 2011; Strickland, Miller \& Wooden, 2011). Basement rocks of Archean, Palaeoproterozoic and Mesoproterozoic ages can be found throughout the entire studied area (Fig. 10c). Archean ages are found in Wyoming, southwestern Montana and northeastern Nevada (Fig. 10c; Fan et al. 2011; Mueller et al. 2011; Nelson, Hart \& Frost, 2011; Strickland, Miller \& Wooden, 2011). Palaeoproterozoic ages are found in Utah and eastern Nevada (Fig. 10c; Mueller et al. 2011; Nelson, Hart \& Frost, 2011). Finally, Mesoproterozoic ages associated with metamorphism are found in northwestern Utah and northern Idaho (Fig. 10c; Foster et al. 2006; Mueller et al. 2011; Nelson, Hart \& Frost, 2011).

Five different lithospheric terranes composing the SFB basement can therefore be identified: the Wyoming Terrane (WT); the Grouse Creek Block (GCB); the Mojave Terrane (MT); the Yavapai Terrane (YT); and the Farmington Terrane (FT; Fig. 10d). The GCB and WT are Archean terranes with ages of c. $2.5<5>\mathrm{Ga}$ (Nelson, Hart \& Frost, 2011; Strickland, Miller \& Wooden, 2011) and 2.4-3.3<5>Ga (Fan et al. 2011; Mueller et al. 2011), respectively. The MT is a Palaeoproterozoic terrane of age $2.04-2.34<5>\mathrm{Ga}$, whereas the YT is a younger Palaeoproterozoic terrane of age $1.720-1.744<5>\mathrm{Ga}$ (Nelson, Hart \& Frost, 2011). The FT is a Mesoproterozoic intracratonic mobile belt (Lund et al. 2015) composed of reworked Archean crust (Whitmeyer \& Karlstrom, 2007), with metamorphism ages between 1.63 and $1.71<5>\mathrm{Ga}$ (Foster et al. 2006; Mueller et al. 2011; Nelson, Hart \& Frost, 2011).

\section{4.c. Impact of the heritage on the SFB development}

The fact that the basement of the SFB is composed of five Archean-Mesoproterozoic terranes questions the potentially crucial role of inherited lithospheric features on the formation and spatio-temporal evolution of the SFB.

Lithospheric strength (i.e. rigidity) of the terranes varies depending on their age and heritage (Poudjom Djomani et al. 2001; Artemieva \& Mooney, 2002), with important changes in rheological behaviour and segregation between oldest $(>1.7<5>\mathrm{Ga})$ and juvenile 
crusts $(<1.7<5>\mathrm{Ga}$; Artemieva \& Mooney, 2002). Since older lithospheres are more rigid than younger, Archean and Palaeoproterozoic basements such as the Wyoming Terrane, Grouse Creek Block, Mojave Terrane and Yavapai Terrane are defined here as 'strong' lithospheres (e.g. Cardozo \& Jordan, 2001; Leever et al. 2006; Fig. 11). Conversely, the more recent Mesoproterozoic lithospheres such as the Farmington Terrane (Fig. 11) are characterized by a lower rigidity (e.g. Cardozo \& Jordan, 2001; Leever et al. 2006; Fosdick, Graham \& Hilley, 2014). Additionally, some lithospheres can be weaker than coeval ones due to their structural heritage and thermal history, and are assumed to be 'attenuated' (sensu Fosdick, Graham \& Hilley, 2014). The Farmington Terrane was formed as a mobile belt between Archean GCB and WT and underwent at least one event of intense thermal metamorphism during Mesoproterozoic time (Mueller et al. 2011; Lund et al. 2015) Younger occurrences of similar events until Early Triassic time cannot be ruled out, especially given the Bouguer gravity anomaly hints of underplating dense material (see Section 4.b). The Farmington Terrane is therefore considered here as a 'thermally attenuated weak' lithosphere (Fig. 11).

Due to the lithospheric heterogeneity of the basement, the role of the boundary lithospheric faults can be considered as essential. Neoarchean-Palaeoproterozoic terranes are limited by mega-shear zones along with deep (nearly) vertical crustal and/or lithospheric faults (Figs 10d, 11). Terranes in the SFB display some characteristics (e.g. dimension, geometry) that are similar to the terranes associated with the Neoarchean-Palaeoproterozoic accretionary orogens (e.g. Chardon, Gapais \& Cagnard, 2009, fig. 2; Cagnard, Barbey \& Gapais, 2011, fig. 9). These lithospheric and crustal accidents have therefore been reactivated since their Precambrian onset (e.g. Bryant \& Nichols, 1988; Paulsen \& Marshak, 1999). Additionally, several authors (e.g. Eardley, 1939; Peterson, 1977) identified the presence of a topographic basement highland (pale blue area in Fig. 12a, in colour online) near the junction between the MT and the GCB/FT/WT during Palaeozoic time, separating the northern and southern areas of marked sedimentary accumulation. Eardley (1939) first introduced this feature as the 'Northern Utah Highland'. Peterson (1977) highlighted its presence on his palinspastic maps for the Palaeozoic stratigraphic record. Finally, this sedimentary and topographic pattern seems to have been the same in this basin since Proterozoic time (Paulsen \& Marshak, 1999; Fig. 12a). 
By the time of the initiation of the Sonoma orogeny, this difference in sedimentary accumulation was well marked in Palaeozoic series (Peterson, 1977). For instance, about $6<5>\mathrm{km}$ of marine sediments accumulated in the Permian Oquirrh Basin in the northern part of the SFB (Fig. 12a; Yonkee \& Weil, 2015), whereas the southern part of the SFB saw the deposition of only several hundred metres of marine and terrigenous sediments (e.g. c. $640<5>\mathrm{m}$ in southwestern Utah; Rowley et al. 2005) during the same interval. The thick Palaeozoic sedimentary series in northern and southern parts of the foreland (Peterson, 1977) would have allowed the thrust belt to propagate, while the presence of the topographic basement highland characterized by a reduced sedimentary cover should have triggered the formation of a lateral ramp and a recess in the central part of the front (Fig. 12a). The presence of the topographic high is attested by the occurrence of shallow conglomerates in the western part of the SFB within the PTU-Smithian interval (Fig. 12a, b; e.g. Gabrielse, Snyder \& Stewart, 1983; Lucas \& Orchard, 2007; Jattiot et al. in press). Previous reconstruction of the GA thrust front also accounted for the presence of a recess in the central part of the thrust front (e.g. Dickinson, 2006, 2013). Moreover, this mechanism underlying the observed differential propagation has been proposed by Paulsen \& Marshak (1999) for the Sevier thrust-and-fold belt which shows the presence of a lateral ramp in its central part (Fig. 2). This was explained by the pre-deformational sedimentary thicknesses pattern showing thrusts propagating further when emplaced upon a thicker sedimentary cover (Figs 2, 12a; Paulsen \& Marshak, 1999, fig. 7). It is worth noting that both the lateral ramps of the Sevier and Golconda thrust-and-fold belt are located close to and along the lithospheric boundary between the MT and FT/WT (Figs 2, 12a). basement heritage, over the flexural response of the SFB. However, due to the scarcity of allochthon remnants, a numerical model is required to decipher its potential role.

\section{4.d. Simulating the flexural response of the basin}

All the data discussed above have been integrated in a 2D numerical flexural model. This approach allows us to quantify in a predictive way the flexural behaviour of the basin in relation to its basement heritage. 

code written in Matlab® (Le Pourhiet \& Saleeby, 2013; Moreau et al. 2015). It solves

$$
\nabla^{2}\left(D \nabla^{2} \omega\right)=g\left(\rho_{\mathrm{m}}-\rho_{\mathrm{i}}\right)+q
$$

503 for flexural deflection $\omega$ of a thick elastic plate (Reissner-Mindlin approximation) using bilinear isoparametric elements with under integration technique for the shear terms (Zienkiewicz \& Taylor, 2005). In Equation (1) the rigidity of the plate $D$, defined

506

$$
D=\frac{E T_{\mathrm{e}}^{3}}{12\left(1-v^{2}\right)},
$$

507

depends solely on the effective elastic thickness $T_{\mathrm{e}}$ as the plate Young's modulus $E$ and Poisson's ratio $v$ are fixed at $80<5>\mathrm{GPa}$ and 0.25 , respectively (Burov \& Diament, 1995). The topographic loads $q=\rho_{\mathrm{t}} g h$ account for the thickening $h$ resulting from the orogeny and are computed using a density $\rho_{\mathrm{t}}=2700<5>\mathrm{kg} \mathrm{m}^{-3}$. The mantle restoring forces are computed assuming a density $\rho_{\mathrm{m}}=3300<5>\mathrm{kg} \mathrm{m}^{-3}$, while the infill is considered to be sediments of density $\rho_{\mathrm{i}}=1600<5>\mathrm{kg} \mathrm{m}^{-3}$. We arbitrarily attributed a constant height $h=1500<5>\mathrm{m}$ to the topographic load as we concentrate on the effect of heterogeneities of the allochthon morphology and rheology of the basement only. These initial parameters are summarized in Table 2 .

The models are $907<5>\mathrm{km}$ wide in the $x$ direction, chosen to be normal to the trend of the orogenic belt, and $1166<5>\mathrm{km}$ in the $y$ direction. We assume that isostatic compensation is achieved underneath the orogen and, accordingly, we set the curvature normal to the right side to zero, $\partial \omega / \partial x=0$. As the orogen is very long compared to the region where flexural subsidence is analysed, we enforce cylindrical boundary conditions on the side of normal $y$ $(\partial \omega / \partial y=0)$. On the right boundary, that is, far from the orogeny, the effect of topographic loading can be considered null, corresponding to $\omega=0$.

In this model, we used $T_{\mathrm{e} 1}=90<5>\mathrm{km}$ for the 'strong' GCB, WT, MT and YT lithospheres (Table 2), which is a good approximation for cratonic $T_{\mathrm{e}}$ (Watts, 1992). The 'weak-attenuated' FT is expected to show a contrasted lower $T_{\mathrm{e}}$ value due to its assumed 
526 rheological weaknesses. This value was set at $T_{\mathrm{e} 2}=30<5>\mathrm{km}$ (Table 2; e.g. Leever et al.

527 2006).

528

529

530

531

532

533

534

535

536

537

538

539

540

541

542

543

544

545

546

547

548

549

550

551

552

553

554

\section{4.d.2. Model results}

Figure 13 shows that the southern part of the front is reconstructed as less propagated into the foreland than the northern part (Fig. 12a; see Dickinson, 2006, 2013). In this model, the lateral ramp is spatially restricted along the limit between the FT/WT and MT (Fig. 13a). The northern part, emplaced mainly above the 'weak' FT and in front of the largest part of the GA, presents a narrower foredeep with $\lambda \approx 250<5>\mathrm{km}$ (Fig. 13a, b). The steep foredeep is bordered by a well-expressed forebulge emplaced close to the FT/WT boundary (Fig. 13a; $X X$ ' in Fig. 13b). The southern part of the foreland is set upon 'strong' lithospheres (MT and YT) in front of the smallest and recessed parts of the GA (Fig. 13a, c). The foredeep in this part of the model is larger, with $\lambda \approx 320<5>\mathrm{km}$, and its profile ( $Y Y^{\prime}$ ' in Fig. 13c) also exhibits a weaker topography than in the northern part. We also notice the presence of a barely expressed forebulge in this area (Fig. 13a, c).

The dichotomy between the northern and southern parts is especially obvious on a N-S transect ( $Z Z$ ' in Fig. 13d). A shallow southern sub-basin with a gentle northwards dip (< c. $250<5>\mathrm{m}$ deep) is identified, as well as a northern deeper basin with steep borders (c. $600<5>\mathrm{m}$ deep). The limit between the northern and southern parts appears relatively close to the MT/FT boundary (Fig. 13d), suggesting a significant role for lithospheric boundaries in the differential flexuration of the SFB. This N-S differentiation is found not only in the foreland, but also within the allochthon itself as its simulated elevation is not continuous along its front (Fig. 13a). Two areas of important elevations $(>1200<5>$ m) can be observed on both the northern and southern sides of the GA recess. This positive relief could have contributed as a significant source of terrigenous material, then being deposited in the proximal foreland.

\section{Discussion}

Our results highlight the spatial differences in subsidence within the SFB, especially between its northern and southern parts (Figs 8, 9). This differential subsidence is underlined by variations in the sedimentary record (Figs 4, 5). In addition, a highland was probably 
555 present in the central SFB and could physically have partly separated these two parts of the 556 basin.

\section{5.a. Evidence for a foreland basin}

The convex 'lozenge shape' (sensu Miall, 2010) of the isopach map (Fig. 8) and the

559

560

561

562

563

564

565

566

567

568

569

570

571

572

573

574

575

576

577

578

579

580

581

582

583

584 westwards-thickening pattern of the sedimentary record are in agreement with the common asymmetric geometry of foreland basins (Fig. 8; DeCelles \& Giles, 1996; Miall, 2010). Additionally, the observed high-rate subsidence values (c. $100-500<5>\mathrm{m} \mathrm{Ma}^{-1}$ ) agree with foreland basin dynamics, even if these values are greater in magnitude than values generally given in the literature for similar contexts (e.g. Xie \& Heller, 2009). This difference in magnitude is interpreted by considering that estimations from backstripping analyses are generally proposed for continuous sedimentary series spanning several millions years, if not several tenth of millions years (e.g. Xie \& Heller, 2009). Over such long time intervals, the subsidence rate values are less accurate. The high resolution of the timeframe used for the SFB mirrors short-acting structural events in the basin. Similar 'higher than average' values for subsidence rates have been calculated by Chevalier et al. (2003) and Lachkar et al. (2009) using high-resolution biostratigraphic time-calibrations, and also by Roddaz et al. (2010) with similar magnitude for the Miocene Amazonian Foreland Basin (c. 200-700<5>m Ma-1; Roddaz et al. 2010). Moreover, values observed in the SFB $\left(0.05-0.65 \mathrm{~mm} \mathrm{a}^{-1}\right)$ are consistent with yearly deposition rates indicated by Allen \& Allen (2005) for foreland basins (0.2$0.5<5>\mathrm{mm} \mathrm{a}^{-1}$ ). Finally, the convex-up shape of the tectonic subsidence curves (Fig. 9f) is diagnostic of foreland basins and corresponds to the progressive flexural response of the lithosphere to the topographic load and/or sedimentary infill of the basin overtime (Angevine, Heller \& Paola, 1990; Allen \& Allen, 2005; Xie \& Heller, 2009).

In the SFB, the topographic load is exerted by the GA. This allochthon has been emplaced on the North American continental margin, as evidenced by the geochemical signature of the Koipato Formation volcanics (Early Triassic) originating from the partial melting of a Palaeoproterozoic continental crust (likely the Mojave Terrane; Vetz, 2011).

The observed spatial heterogeneity of the sedimentary thickness in the SFB (Figs 4, 8) and the much higher tectonic subsidence rate detected in the northern part of the basin (c. $500<5>\mathrm{m} \mathrm{Ma}^{-1}$ v. c. $100<5>\mathrm{m} \mathrm{Ma}^{-1}$ in the southern part; Fig. 9f) are striking and raise the 
question of the controlling factor(s) responsible for this phenomenon, especially for such a short interval (c. $1.3<5>\mathrm{Ma})$.

\section{5.b. Potential underlying mechanisms for observed variations in flexural subsidence}

Spatial variations in subsidence within the SFB may result from different mechanisms that are inherent to the flexural nature of the foreland basin: (1) the sedimentary overload provoked by the continuous filling of the basin over time; (2) the spatial heterogeneity of the GA (topography and shape of the load); and/or (3) the differential flexural response of the lithosphere to this topographic load and linked to the rheology of the basement.

Considering point (1) above, in some cases the distributed vertical load exerted by the sedimentary filling of the basin might affect and amplify the flexuration in foreland basins over time (Shanmugam \& Walker, 1980; Beaumont, 1981; Cardozo \& Jordan, 2001; Allen \& Allen, 2005). As this load depends mainly on the sedimentary fluxes and density of the filling, a denser deposited material leads to a more important flexuration of the lithosphere, as modelled by Angevine, Heller \& Paola (1990) and Fosdick, Graham \& Hilley (2014). The southern part of the SFB, characterized by low subsidence rates, exhibits coarse clastic sedimentation in the Moenkopi Group with the presence of conglomerates and sandstones (Figs 3a, 4, 5b, c, e, 12; e.g. Gabrielse, Snyder \& Stewart, 1983; Olivier et al. 2016) of density 2.5-2.8<5> $\mathrm{kg} \mathrm{cm}^{-3}$ (Manger, 1963; McCulloh, 1967; Sclater \& Christie, 1980; Tenzer et al. 2011). The top of the Moenkopi Group consists of thick microbial limestone beds (Figs 3a, 4, 5e; e.g. Olivier et al. 2014, 2016; Vennin et al. 2015). These limestones bear a density of c. 2.6-2.8<5> $\mathrm{kg} \mathrm{cm}^{-3}$ (Manger, 1963; McCulloh, 1967; Sclater \& Christie, 1980; Tenzer et al. 2011). In contrast, the northern part which is characterized by high subsidence rates, is dominated by marine siltstones of the Dinwoody and Woodside Formation (Figs 3a, 4, 5g; e.g. Kummel, 1954, 1957). The density of this type of sediment is of 2.3$2.7<5>\mathrm{kg} \mathrm{cm}^{-3}$ (Manger, 1963; Sclater \& Christie, 1980; Tenzer et al. 2011). Based on these data, the sedimentary filling should have had a higher impact on the flexuration in the southern part of the basin. However, we show that the most important subsidence during the PTU-Smithian interval took place in the northern part of the SFB (Figs 8, 9). Moreover, the difference between tectonic and total subsidence mainly consist of the local isostasy and 
compaction of the sediments (Allen \& Allen, 2005). With the tectonic subsidence being the most important component of the total subsidence in the SFB (Fig. 9a), this argues for a weak potential role of the sedimentary load. The sedimentary overload therefore cannot be a major controlling factor explaining the differential flexuration observed within the basin.

Regarding points (2) and (3) above, while it is possible to discuss the role of the sedimentary overload using only field-based data, interpretations of the allochthon heterogeneity and the basement rheological behaviour require an additional model approach. We combine these in the following discussion. To that purpose, we used three different scenarios (Fig. 14) with the same initial setup (Section 4.d; Table 2) except for the $x$ and $y$ dimensions of the model that are set to $2000<5>\mathrm{km}$ in the $x$ direction and $1000<5>\mathrm{km}$ in the $y$ direction to avoid border effects.

The first scenario tests the impact of a rheologically heterogeneous basement loaded by a homogeneous allochthon (Fig. 14a). The rigidity of the terrane controls its capacity to flexure. The shape of ensuing flexural foreland basins and the distribution of their sedimentary records are therefore a direct consequence of the rheological behaviour of the basement (Angevine, Heller \& Paola, 1990; Watts, 1992; Cardozo \& Jordan, 2001; Allen \& Allen, 2005; Leever et al. 2006; Fosdick, Graham \& Hilley, 2014). Upon the high-rigidity part of the basement $\left(T_{\mathrm{e} 1}\right)$, a wide foreland $\left(\lambda_{1} \approx 250<5>\mathrm{km}\right)$ develops with a well-expressed convex shape in map view and a barely expressed forebulge. Upon the low-rigidity parts of the basement $\left(T_{\mathrm{e} 2}\right)$, a narrower foreland $\left(\lambda_{2} \approx 110<5>\mathrm{km}\right)$ is structured with a more pronounced forebulge. This is in agreement with the SFB observations. However, a N-S transect ( $a a^{\prime}$, Fig. 14a) shows that the wider area of the foreland basin is deeper than observed in the field and that only one high-relief area is individualized within the central part of the allochthon. Even if the rigidity does play a role in the development of the flexural foreland basin, as commonly assumed in the literature (Angevine, Heller \& Paola, 1990; DeCelles \& Giles, 1996; Cardozo \& Jordan, 2001; Allen \& Allen, 2005; Leever et al. 2006; Miall, 2010; Fosdick, Graham \& Hilley, 2014), our results indicate that a rheological difference is not enough to control the variations in SFB.

The second scenario uses a heterogeneous topographic load exerted by the allochthon upon a homogeneous 'strong' lithosphere $\left(T_{\mathrm{e}}=90<5>\mathrm{km}\right.$; Fig. 14b). The heterogeneity in the 
allochthon is introduced in the form of a $c .100<5>\mathrm{km}$ wide recess (i.e. a lateral ramp) along its front. The foreland basin shows a larger area $\left(\lambda_{1} \approx 180<5>\mathrm{km}\right)$ in front of the lateral ramp compared to the northern and southern parts $\left(\lambda_{2} \approx 100<5>\mathrm{km}\right)$. Moreover, a N-S transect ( $b b^{\prime}$ in Fig. 14b) shows that the narrow northern part of the basin is deeper than in front of the recess. An important relief is also formed in the corners of the allochthon on both lateral borders of the recess. This is in agreement with SFB observations. However, the overall shape of the foreland basin is rather concave and enters in the recess significantly. Even if the morphology of the allochthon plays a role in the development of the foreland basin, this numerical scenario shows marked differences with the SFB.

The third scenario combines both previously tested heterogeneities (Fig. 14c). The graphic output exhibits a wider foreland $\left(\lambda_{1} \approx 350<5>\mathrm{km}\right)$ emplaced above the 'strong' lithosphere in front of the recess, and a narrow foreland $\left(\lambda_{2} \approx 100<5>\mathrm{km}\right)$ above 'weak' lithospheres. This model reproduces well the convex shape of the foreland basin with a marked forebulge development upon 'weak' lithospheres, whereas it is less pronounced upon the strong lithosphere. Moreover, a N-S transect ( $c c^{\prime}$ in Fig. 14c) highlights a deeper area upon the 'weak' lithosphere. Finally, a prominent relief of the allochthon is observed on both corners bordering the recess.

To summarize, from the three possible mechanisms proposed to explain the origin of the differential flexural subsidence in the SFB, only the combined effect of the heterogeneous rheology of the basement and the spatial heterogeneity of the GA can be considered as the major controlling factors.

\section{5.c. Combined outcomes of heterogeneities over differential subsidence}

Our field data highlight the contrasted subsidence between the northern and southern parts of the SFB. The numerical model provides a complement to discuss the potential combined outcomes of rheology and allochthon heterogeneities. Congruent features between the numerical model of the SFB (Fig. 13), the tested scenarios (Fig. 14) and field data (Fig. 15) indeed argue for a major controlling role of the allochthon spatial heterogeneities and of the basement rheological behaviour on the formation and development of the SFB during Early Triassic time. As these two parameters are directly linked to the age, nature and 
674 pattern of the basement terranes, the lithosphere heritage likely controls the flexuration and 675 therefore the subsidence variations documented for the Early Triassic SFB.

677 Figure 15. The northern part of the basin (section $A A^{\prime}$ ) is characterized by a narrow foredeep

$678(\lambda \approx 250<5>\mathrm{km})$ with a high-rate tectonic subsidence $\left(c .500<5>\mathrm{m} \mathrm{Ma}^{-1}\right)$ and high sedimentary thickness (up to $c$. 550<5>m of mostly fine siltstones deposits), which is located upon the 'weak/attenuated' Farmington Terrane and in front of the largest reconstructed part of the GA. The postulated wedge-top and forebulge are located above the 'strong' Archean lithospheres, that is, the GCB and WT, respectively. The southern part of the SFB exhibits a large foredeep $\left(\lambda \approx 500<5>\mathrm{km}\right.$, section $\left.B B^{\prime}\right)$ with a relatively low-rate tectonic subsidence (c. $100<5>\mathrm{m} \mathrm{Ma}^{-1}$ ) and a reduced sedimentary thickness (up to $c .250<5>\mathrm{m}$ of mixed limestones and coarse clastic deposits). This part of the SFB is emplaced upon the 'strong' lithospheres of the Palaeoproterozoic MT and YT, in front of the thinnest reconstructed part of the GA. The southern SFB also shows a reduced postulated wedge-top to the west and a barely expressed forebulge to the east. These spatial variations in flexural subsidence and their good agreement with limits of the terranes composing the SFB basement are also evident along a $\mathrm{N}-\mathrm{S}$ transect (section $C C^{\prime}$ ). The spatial separation between the shallow and gently dipping southern part of the SFB and the deep and steep northern part is obvious. This separation is located close to the boundary between MT and FT.

\section{Conclusion}

In this study, we used an integrated approach to decipher the major role of the lithospheric heritage over the differential sedimentary deposition in the Sonoma Foreland Basin during Early Triassic time. Our approach used both field-based sedimentary data, calibrated within a highly resolved biostratigraphic framework, and numerical model to test the influence of several potential controlling factors. Palinspastic reconstructions were also performed to obtain an accurate palaeogeographic context.

Using high-resolution temporal data, the subsidence analyses help to identify the main controlling factors at the origin of the spatial variations of the Early Triassic sedimentary record in the SFB. The sedimentary overload cannot satisfactorily explain the observed 
variations in thickness of the sedimentary record throughout the basin. The combined effects of the contrasted lithospheric strength of the terranes ('weak' v. 'strong' lithospheres) composing the basement of the basin, and the spatial heterogeneity of the Golconda Allochthon (with the presence of a lateral ramp within the belt), best explain a differential flexural response of the SFB basement to the emplacement of the allochthon. Such a differential flexural response ultimately controls the overall geometry of the basin through spatially heterogeneous tectonic subsidence rates: $c$. $100<5>\mathrm{m} \mathrm{Ma}^{-1}$ in a wide southern part upon a 'strong' lithosphere loaded by a recessed and thin (in map-view) front belt, v. c. $500<5>\mathrm{m} \mathrm{Ma}^{-1}$ in a narrower northern part upon a 'weak/attenuated' lithosphere loaded by a larger front belt. Although field data highlight the potential role of the rheological behaviour of the basement based on observed differential subsidence rates, the numerical model approach suggests a combined effect of the latter and of the spatial heterogeneity of the allochthon.

As heterogeneities of the basement and in the morphology of the allochthon result from the nature and history of the different lithospheric terranes that compose the basement, the lithosphere heritage likely played a prime role in controlling the development of the Sonoma Foreland Basin during Early Triassic time, and consequently generated the observed variations of the sedimentary record through differential subsidence.

\section{Acknowledgements}

We particularly thank the late Professor W.R. Dickinson for constructive discussions. We also thank Hugo Bucher and Romain Jattiot (Zürich) for discussion on Nevada outcrops. This work is a contribution to the ANR project AFTER (ANR-13-JS06-0001-01). The study was also supported by 725 ENGIE.

\section{Supplementary material} https://doi.org/10.1017/S0016756817000164. 
Blackwell Science Publishing.

Angevine, C. L., Heller, P. L. \& PaOla, C. 1990. Quantitative Sedimentary Basin Modeling. American Association of Petroleum Geologists.

ARtemieVA, I. M. \& MoONEY, W. D. 2002. On the relations between cratonic lithosphere thickness, plate motions, and basal drag. Tectonophysics 358(1-4), 211-31.

Bankey, V. A., Cuevas, D., Daniels, A. A., Finn, C. A., Hernandez, I., Hill, P., Kucks, R., Miles, W., Pilkington, M., Roberts, C., Roest, W., Rystrom, V., Shearer, S., Snyder, S., Sweeney, R., Velez, J., Phillips, J. D. \& Ravat, D. 2002. Digital data grids for the magnetic anomaly map of North America. Open-File Report 02-414: USGS.

BEAUMONT, C. 1981. Foreland basins. Geophysical Journal International 65(2), 291-329.

BlaKey, R. C. 2008. Pennsylvanian-Jurassic sedimentary basins of the Colorado Plateau and Southern Rocky Mountains. Sedimentary Basins of the World, pp. 245-96. Netherlands: Elsevier.

Bond, G. C., Christie-Blick, N., Kominz, M. A. \& Devlin, W. J. 1985. An early Cambrian rift to post-rift transition in the Cordillera of western North America. Nature 315, $742-46$.

Brayard, A., Bylund, K. G., Jenks, J. F., Stephen, D. A., Olivier, N., Escarguel, G., FARA, E. \& VENNIN, E. 2013. Smithian ammonoid faunas from Utah: implications for Early Triassic biostratigraphy, correlation and basinal paleogeography. Swiss Journal of Palaeontology 132(2), 141-219.

Brayard, A., Meier, M., Escarguel, G., Fara, E., Nuetzel, A., Olivier, N., Bylund, K. G., Jenks, J. F., Stephen, D. A., Hautmann, M., Vennin, E. \& Bucher, H. 2015. Early Triassic 'Gulliver' gastropods; spatio-temporal distribution and significance for biotic recovery after the end-Permian mass extinction. Earth-Science Reviews 146, 31-64.

BRÜHWILER, T., Bucher, H., Brayard, A. \& Goudemand, N. 2010. High-resolution biochronology and diversity dynamics of the Early Triassic ammonoid recovery; the Smithian faunas of the northern Indian margin. Palaeogeography, Palaeoclimatology, Palaeoecology 297(2), 491-501.

BRYANT, B. \& NichOLS, D. 1988. Late Mesozoic and early Tertiary reactivation of an ancient crustal boundary along the Uinta trend and its interaction with the Sevier orogenic 
belt. Geological Society of America Memoirs 171, 411-30.

Bucher, H. 1988. A new Middle Anisian (Middle Triassic) ammonoid zone from northwestern Nevada (USA). Eclogae Geologicae Helvetiae 81(3), 723-62.

BURCHFIEL, B. \& DAVIS, G. A. 1975. Nature and controls of Cordilleran orogenesis, western United States: Extensions of an earlier synthesis. American Journal of Science 275, 363-96.

BurChFiel, B. \& Royden, L. 1991. Antler orogeny: A Mediterranean-type orogeny. Geology 19(1), 66-9.

Burgess, S. D., Bowring, S. \& SHEN, S.-Z. 2014. High-precision timeline for Earth's most severe extinction. Proceedings of the National Academy of Sciences of the United States of America 111(9), 3316-21.

Burov, E. B. \& DiAmEnT, M. 1995. The effective elastic thickness $\left(\mathrm{T}_{\mathrm{e}}\right)$ of continental lithosphere: What does it really mean? Journal of Geophysical Research: Solid Earth 100(B3), 3905-27.

Cagnard, F., Barbey, P. \& GaPAis, D. 2011. Transition between "Archaean-type” and "modern-type" tectonics: insights from the Finnish Lapland Granulite Belt. Precambrian Research 187(1), 127-42.

CARdozo, N. \& JoRdAn, T. 2001. Causes of spatially variable tectonic subsidence in the Miocene Bermejo Foreland Basin, Argentina. Basin Research 13(3), 335-57.

Chamberlain, R. L. 1980. Structure and stratigraphy of the Rex Peak Quadrangle, Rich County, Utah. Geology Studies 27, Part 3, 44-54.

ChARDOn, D., GAPAis, D. \& CAGNARD, F. 2009. Flow of ultra-hot orogens: a view from the Precambrian, clues for the Phanerozoic. Tectonophysics 477(3), 105-18.

Chevalier, F., Guiraud, M., Garcia, J. P., Dommergues, J. L., Quesne, D., Allemand, P. \& DumONT, T. 2003. Calculating the long-term displacement rates of a normal fault from the high-resolution stratigraphic record (early Tethyan rifting, French Alps). Terra Nova 15(6), 410-16.

Clark, D. L. 1957. Marine Triassic stratigraphy in eastern Great Basin. AAPG Bulletin 41(10), 2192-222.

ConeY, P. J. 1987. The regional tectonic setting and possible causes of Cenozoic extension in the North American Cordillera. Geological Society Special Publications 28, 177-86.

Constenius, K. N., Clark, D. L., King, J. K. \& Ehler, J. B. 2011. Interim geologic map of 
the Provo 30' x 60' quadrangle, Utah, Wasatch, and Salt Lake Counties, Utah. In Utah Geological Survey Open-File Report 586DM (ed. U. G. Survey).

DeCelles, P. G. \& CoOgan, J. C. 2006. Regional structure and kinematic history of the Sevier fold-and-thrust belt, central Utah. Geological Society of America Bulletin 118(7-8), 841-64.

DeCelles, P. G. \& Giles, K. A. 1996. Foreland basin systems. Basin Research 8(2), 10523.

DICKERSON, P. W. 2003. Intraplate mountain building in response to continent-continent collision; the ancestral Rocky Mountains (North America) and inferences drawn from the Tien Shan (Central Asia). Tectonophysics 365(1-4), 129-42.

DiCKInSON, W. R. 2002. The Basin and Range Province as a composite extensional domain. International Geology Review 44(1), 1-38.

DiCKINSON, W. R. 2004. Evolution of the North American cordillera. Annual Review of Earth and Planetary Sciences 32, 13-45.

Dickinson, W. R. 2006. Geotectonic evolution of the Great Basin. Geosphere 2(7), 353-68.

DICKINSON, W. R. 2013. Phanerozoic palinspastic reconstructions of Great Basin geotectonics (Nevada-Utah, USA). Geosphere 9(5), 1384-96.

Doelling, H. H. 1980. Geology and Mineral Resources of Box Elder County, Utah. Salt Lake City, UT: Utah Geological and Mineral Survey.

EARDLEY, A. J. 1939. Structure of the Wasatch-Great Basin region. Geological Society of America Bulletin 50(8), 1277-310.

EMBRY, A. F. 1997. Global sequence boundaries of the Triassic and their identification in the Western Canada sedimentary basin. Bulletin of Canadian Petroleum Geology 45(4), 415-33.

Fan, M., DeCelles, P. G., Gehrels, G. E., Dettman, D. L., Quade, J. \& Peyton, S. L. 2011. Sedimentology, detrital zircon geochronology, and stable isotope geochemistry of the lower Eocene strata in the Wind River Basin, central Wyoming. Geological Society of America Bulletin 123(5-6), 979-96.

Fletcher, R. C. \& Hallet, B. 1983. Unstable extension of the lithosphere: A mechanical model for basin-and-range structure. Journal of Geophysical Research: Solid Earth 88(B9), 7457-66.

Fosdick, J. C., Graham, S. A. \& Hilley, G. E. 2014. Influence of attenuated lithosphere 
and sediment loading on flexure of the deep-water Magallanes retroarc foreland basin, Southern Andes. Tectonics 33(12), 2505-25.

Foster, D. A., Mueller, P. A., Mogk, D. W., Wooden, J. L. \& Vogl, J. J. 2006.

Proterozoic evolution of the western margin of the Wyoming craton: implications for the tectonic and magmatic evolution of the northern Rocky Mountains. Canadian Journal of Earth Sciences 43(10), 1601-19.

Gabrielse, H., SNyder, W. S. \& Stewart, J. H. 1983. Sonoma orogeny and Permian to Triassic tectonism in western North America. Geology 11(8), 484-86.

Galfetti, T., Bucher, H., Ovtcharova, M., Schaltegger, U., Brayard, A., Brühwiler, T., Goudemand, N., Weissert, H., Hochuli, P. A., Cordey, F. \& GuODun, K. 2007. Timing of the Early Triassic carbon cycle perturbations inferred from new $\mathrm{U}-\mathrm{Pb}$ ages and ammonoid biochronozones. Earth and Planetary Science Letters 258(3-4), 593-604.

GANS, P. \& BOHRSON, W. 1998. Suppression of volcanism during rapid extension in the Basin and Range Province, United States. Science 279(5347), 66-68.

GESLIN, J. K. 1998. Distal ancestral Rocky Mountains tectonism: Evolution of the Pennsylvanian-Permian Oquirrh-Wood River basin, southern Idaho. Geological Society of America Bulletin 110(5), 644-63.

Gilbert, H., Velasco, A. A. \& ZAndT, G. 2007. Preservation of Proterozoic terrane boundaries within the Colorado Plateau and implications for its tectonic evolution. Earth and Planetary Science Letters 258(1-2), 237-48.

GoodsPeEd, T. H. \& LuCAS, S. G. 2007. Stratigraphy, sedimentology, and sequence stratigraphy of the Lower Triassic Sinbad Formation, San Rafael Swell, Utah. Bulletin - New Mexico Museum of Natural History and Science 40, 91-101.

Groshong JR, R. H. 2006. 3-D Structural Geology. Springer.

HaQ, B. U., Hardenbol, J. \& VAIL, P. R. 1988. Mesozoic and Cenozoic chronostratigraphy and cycles of sea-level change. In:, pp. 72-108. Society of Economic Paleontologists and Mineralogists, Special Publication no. 42.

Heckert, A. B., Chure, D. J., Voris, J. T., Harrison, A. A. \& Thomson, T. J. 2015. Stratigraphy, correlation and age of the Moenkopi Formation in the vicinity of Dinosaur National Monument, Eastern Uinta Basin, Utah and Colorado, USA. In Geology of Utah's Uinta Basin and Uinta Mountains (eds M. D. Vanden Berg, R. 
Ressetar and L. P. Birgenheier), pp. 1-12. Utah Geological Association Publication. Hofmann, R., Hautmann, M., Brayard, A., Nuetzel, A., Bylund, K. G., Jenks, J. F., VenNin, E., Olivier, N. \& Bucher, H. 2014. Recovery of benthic marine communities from the end-Permian mass extinction at the low latitudes of eastern Panthalassa. Palaeontology 57(3), 547-89.

INGERSOLL, R. V. 2008. Subduction-related sedimentary basins of the USA Cordillera. In: Sedimentary Basins of the World, pp. 395-428. Amsterdam, Netherlands: Elsevier. Jattiot, R., Bucher, H., Brayard, A., Brosse, M., Jenks, J. \& Bylund, K. G. (in press). Smithian ammonoid faunas from northeastern Nevada: implications for Early Triassic biostratigraphy and correlation within the western USA basin. Palaeontographica Abteilung $A$.

Jattiot, R., Bucher, H., Brayard, A., Monnet, C., Jenks, J. F. \& Hautmann, M. 2015. Revision of the genus Anasibirites Mojsisovics (Ammonoidea): an iconic and cosmopolitan taxon of the late Smithian (Early Triassic) extinction. Papers in Palaeontology 2(1), 155-188.

Kluth, C. F. \& Coney, P. J. 1981. Plate tectonics of the ancestral Rocky Mountains. Geology 9(1), 10-15.

Kreemer, C. \& Hammond, W. C. 2007. Geodetic constraints on areal changes in the Pacific-North America plate boundary zone: What controls Basin and Range extension? Geology 35(10), 943-46.

KUCKS, R. P. 1999. Bouguer gravity anomaly data grid for the conterminous US. US Geological Survey Digital Data Series DDS-9: USGS.

Kummel, B. 1954. Triassic Stratigraphy of Southeastern Idaho and Adjacent Areas. US Government Printing Office.

KUMMEL, B. 1957. Paleoecology of Lower Triassic formations of southeastern Idaho and adjacent areas. Geological Society of America Memoirs 67, 437-68.

LACHEnbruch, A. H. \& Morgan, P. 1990. Continental extension, magmatism and elevation; formal relations and rules of thumb. Tectonophysics 174(1), 39-62.

LachKar, N., Guiraud, M., El Harfi, A., Dommergues, J.-L., Dera, G. \& Durlet, C. 2009. Early Jurassic normal faulting in a carbonate extensional basin; characterization of tectonically driven platform drowning (High Atlas rift, Morocco). Journal of the Geological Society of London 166(3), 413-30. 
LAWTON, T. F., Boyer, S. E. \& Schmitt, J. G. 1994. Influence of inherited taper on structural variability and conglomerate distribution, Cordilleran fold and thrust belt, western United States. Geology 22(4), 339-42.

Le Pourhiet, L. \& SAleeby, J. 2013. Lithospheric convective instability could induce creep along part of the San Andreas fault. Geology 41(9), 999-1002.

Leever, K., Matenco, L., Bertotti, G., Cloetingh, S. \& Drijkoningen, G. 2006. Late orogenic vertical movements in the Carpathian Bend Zone-seismic constraints on the transition zone from orogen to foredeep. Basin Research 18(4), 521-45.

LOWRIE, W. 2007. Fundamentals of Geophysics. Cambridge: Cambridge University Press.

LuCAs, S. G., Krainer, K. \& Milner, A. R. 2007. The type section and age of the Timpoweap Member and stratigraphic nomenclature of the Triassic Moenkopi Group in Southwestern Utah. Triassic of the American West. New Mexico Museum of Natural History and Science Bulletin 40, 109-18.

LUCAS, S. G. \& ORCHARD, M. J. 2007. Triassic lithostratigraphy and biostratigraphy north of Currie, Elko County, Nevada. Bulletin - New Mexico Museum of Natural History and Science 40, 119-26.

Lund, K., Box, S. E., Holm-Denoma, C. S., San Juan, C. A., Blakely, R. J., Saltus, R. W., Anderson, E. D. \& DewitT, E. H. 2015. Basement domain map of the conterminous United States and Alaska. Reston, VA, United States: US Geological Survey.

MALAVIEILLE, J. 1993. Late orogenic extension in mountain belts: insights from the Basin and Range and the late Paleozoic Variscan belt. Tectonics 12(5), 1115-30.

MANGER, G. E. 1963. Porosity and bulk density of sedimentary rocks. USGPO.

MARzolf, J. E. 1993. Palinspastic reconstruction of early Mesozoic sedimentary basins near the latitude of Las Vegas; implications for the early Mesozoic Cordilleran cratonal margin. Field Trip Guidebook - Pacific Section, Society of Economic Paleontologists and Mineralogists 71, 433-62.

MCCulLOH, T. H. 1967. Mass properties of sedimentary rocks and gravimetric effects of petroleum and natural-gas reservoirs. US Government Printing Office.

Miall, A. 2010. The Geology of Stratigraphic Sequences. Springer Science \& Business Media.

Moreau, J., Le Pourhiet, L., Huuse, M., Gibbard, P. L. \& Grappe, B. 2015. The impact 
of the lithospheric flexure during the Elsterian glacial maximum on post-/proglacial systems in the southern North Sea area. In QRA 2015 Annual Discussion Meeting. Mueller, P. A., Wooden, J. L., Mogk, D. W. \& Foster, D. A. 2011. Paleoproterozoic evolution of the Farmington Zone; implications for terrane accretion in southwestern Laurentia. Lithosphere 3(6), 401-08.

Mukul, M. \& MitrA, G. 1998. Finite strain and strain variation analysis in the Sheeprock Thrust Sheet: an internal thrust sheet in the Provo salient of the Sevier Fold-andThrust belt, Central Utah. Journal of Structural Geology 20(4), 385-405.

Nelson, S. T., Hart, G. L. \& Frost, C. D. 2011. A reassessment of Mojavia and a new Cheyenne Belt alignment in the eastern Great Basin. Geosphere 7(2), 513-27.

Newell, N. D. \& KuMMEL, B. 1942. Lower Eo-Triassic stratigraphy, western Wyoming and southeast Idaho. Geological Society of America Bulletin 53(6), 937-96.

Nichols, K. M. \& Silberling, N. J. 1977. Stratigraphy and depositional history of the Star Peak Group (Triassic), northwestern Nevada. Geological Society of America Special Papers 178, 1-74.

Oldow, J. S., Bally, A. W., Avé Lallemant, H. \& Leeman, W. P. 1989. Phanerozoic evolution of the North American Cordillera; United States and Canada. The Geology of North America, 139-232.

Olivier, N., Brayard, A., Fara, E., Bylund, K. G., Jenks, J. F., Vennin, E., Stephen, D. A. \& EsCARGUEL, G. 2014. Smithian shoreline migrations and depositional settings in Timpoweap Canyon (Early Triassic, Utah, USA). Geological Magazine 151(5), 93855.

Olivier, N., Brayard, A., Vennin, E., Escarguel, G., Fara, E., Bylund, K. G., Jenks, J. F., Caravaca, G. \& Stephen, D. A. 2016. Evolution of depositional settings in the Torrey area during the Smithian (Early Triassic, Utah, USA) and their significance for the biotic recovery. Geological Journal 51(4), 600-26.

Parsons, T., Thompson, G. A. \& Sleep, N. H. 1994. Mantle plume influence on the Neogene uplift and extension of the US western Cordillera? Geology 22(1), 83-6.

PAUll, R. A. \& PAUlL, R. K. 1991. Allochthonous rocks from the western part of the early Triassic miogeocline; Hawley Creek area, east-central Idaho. Contributions to Geology 28(2), 145-54.

Paull, R. A. \& PAUlL, R. K. 1993. Interpretation of Early Triassic nonmarine-marine 
relations, Utah, USA. New Mexico Museum of Natural History and Science Bulletin 3, 403-09.

PAulsen, T. \& MARShAK, S. 1999. Origin of the Uinta recess, Sevier fold-thrust belt, Utah: influence of basin architecture on fold-thrust belt geometry. Tectonophysics 312(2), 203-16.

Peterson, J. A. 1977. Paleozoic shelf-margins and marginal basins, western Rocky Mountains-Great Basin, United States. In: Rocky Mountain Thrust Belt, Geology and Resources (eds E. L. Helsey et al.), 135-53. Guidebook Wyo. Geol. Assoc. Annu. Field Conf. 29.

Poudjom Djomani, Y. H., O’Reilly, S. Y., Griffin, W. L. \& Morgan, P. 2001. The density structure of subcontinental lithosphere through time. Earth and Planetary Science Letters 184(3-4), 605-21.

Purucker, M. \& Whaler, K. 2007. Crustal magnetism. Treatise on Geophysics 5, 195-237.

RiouX, R. L., Hite, R. J., Dyni, J. R. \& Gere, W. C. 1975. Geologic map of the Upper Valley Quadrangle, Caribou County, Idaho. Reston, VA, United States: US Geological Survey. Roddaz, M., Hermoza, W., Mora, A., Baby, P., Parra, M., Christophoul, F., Brusset, S. \& Espurt, N. 2010. Cenozoic sedimentary evolution of the Amazonian foreland basin system. In: Amazonia, Landscape and Species Evolution: A Look into the Past. Hoboken: Blackwell-Wiley, 61-88.

Rowley, P. D., Vice, G. S., Mcdonald, R. E., Anderson, J. J., Machette, M. N., Maxwell, D. J., Ekrem, E. B., Cunningham, C. G., Steven, T. A. \& Wardlaw, B. R. 2005. Interim geologic map of the Beaver 30'x60' Quadrangle, Beaver, Piute, Iron, and Garfield Counties, Utah. Utah Geological Survey, Open-File Report 454, scale $1: 100,000$.

SADLER, R. K. 1981. Structure and stratigraphy of the Little Sheep Creek area, Beaverhead County, Montana. United States. Published thesis.

Schelling, D. D., Strickland, D. K., Johnson, K. R. \& VRONA, J. P. 2007. Structural geology of the central Utah thrust belt. Utah Geological Association Publication 36, $1-29$.

Schweickert, R. A. \& LAHren, M. M. 1987. Continuation of Antler and Sonoma orogenic belts to the eastern Sierra Nevada, California, and Late Triassic thrusting in a compressional arc. Geology 15(3), 270-73. 
Sclater, J. G. \& Christie, P. A. F. 1980. Continental stretching: an explanation of the postMid-Cretaceous subsidence of the central North Sea basin. Journal of Geophysical Research 85(B7), 3711-39.

SHANMUGAM, G. \& WALKER, K. R. 1980. Sedimentation, subsidence, and evolution of a foredeep basin in the Middle Ordovician, southern Appalachians. American Journal of Science 280(6), 479-96.

SNYDER, W. S. \& BRUECKNER, H. K. 1983. Tectonic evolution of the Golconda allochthon, Nevada: problems and perspectives.

Speed, R. \& Silberling, N. J. 1989. IGC Field Trip T122: Early Mesozoic tectonics of the Western Great Basin, Nevada. In Early Mesozoic Tectonics of the Western Great Basin, Nevada: Battle Mountain to Yerington District, Nevada, July 1-7, 1989, 1.

SPEED, R. \& SLEEP, N. 1982. Antler orogeny and foreland basin: a model. Geological Society of America Bulletin 93(9), 815-28.

SteCKLER, M. \& WATTS, A. 1978. Subsidence of the Atlantic-type continental margin off New York. Earth and Planetary Science Letters 41(1), 1-13.

Strickland, A., Miller, E. L. \& Wooden, J. L. 2011. The timing of Tertiary metamorphism and deformation in the Albion-Raft River-Grouse Creek metamorphic core complex, Utah and Idaho. Journal of Geology 119(2), 185-206.

Tenzer, R., Sirguey, P., Rattenbury, M. \& Nicolson, J. 2011. A digital rock density map of New Zealand. Computers \& Geosciences 37(8), 1181-91.

Thomazo, C., Vennin, E., Brayard, A., Bour, I., Mathieu, O., Elmeknassi, S., Olivier, N., Escarguel, G., BYlund, K. \& JenKs, J. 2016. A diagenetic control on the Early Triassic Smithian-Spathian carbon isotopic excursions recorded in the marine settings of the Thaynes Group (Utah, USA). Geobiology 14(3), 220-36.

TreXler, J. H. \& NitChMAN, S. P. 1990. Sequence stratigraphy and evolution of the Antler foreland basin, east-central Nevada. Geology 18(5), 422-25.

TURneR, G., RASSON, J. \& REEVES, C. 2007. Observation and measurement techniques. Treatise in Geophysics, Geomagnetism 5, 93-146.

VAN HINTE, J. 1978. Geohistory analysis: application of micropaleontology in exploration geology. AAPG Bulletin 62(2), 201-22.

Vennin, E., Olivier, N., Brayard, A., Bour, I., Thomazo, C., Escarguel, G., Fara, E., Bylund, K. G., Jenks, J. F., Stephen, D. A. \& Hofmann, R. 2015. Microbial 
deposits in the aftermath of the end-Permian mass extinction; a diverging case from the Mineral Mountains (Utah, USA). Sedimentology 62(3), 753-92.

VETZ, N. Q. 2011. Geochronologic and isotopic investigation of the Koipato Formation, northwestern Great Basin, Nevada: implications for Late Permian-Early Triassic tectonics along the Western US Cordillera. Boise State University. Published thesis.

WALKER, J. D. 1985. Permo-Triassic paleogeography and tectonics of the Southwestern United States. Cambridge: Massachusetts Institute of Technology. Published thesis.

Ware, D., Bucher, H., Brayard, A., Schneebeli-Hermann, E. \& Brühwiler, T. 2015. High-resolution biochronology and diversity dynamics of the Early Triassic ammonoid recovery: the Dienerian faunas of the Northern Indian Margin. Palaeogeography, Palaeoclimatology, Palaeoecology 440, 363-73.

WATTS, A. 1992. The effective elastic thickness of the lithosphere and the evolution of foreland basins. Basin Research 4(3-4), 169-78.

WATTS, A. B. 2001. Isostasy and Flexure of the Lithosphere. Cambridge: Cambridge University Press.

Whitmeyer, S. J. \& Karlstrom, K. E. 2007. Tectonic model for the Proterozoic growth of North America. Geosphere 3(4), 220-59.

WiLKERSON, M. S., APOTRIA, T. \& FARID, T. 2002. Interpreting the geologic map expression of contractional fault-related fold terminations: lateral/oblique ramps versus displacement gradients. Journal of Structural Geology 24(4), 593-607.

XIE, X. \& Heller, P. L. 2009. Plate tectonics and basin subsidence history. Geological Society of America Bulletin 121(1-2), 55-64.

Ye, H., Royden, L., Burchfiel, C. \& Schuepbach, M. 1996. Late Paleozoic deformation of interior North America: the greater Ancestral Rocky Mountains. AAPG bulletin 80(9), $1397-432$.

Yonkee, W. A., Dehler, C. D., Link, P. K., Balgord, E. A., Keeley, J. A., Hayes, D. S., Wells, M. L., FAnning, C. M. \& Johnston, S. M. 2014. Tectono-stratigraphic framework of Neoproterozoic to Cambrian strata, west-central US: protracted rifting, glaciation, and evolution of the North American Cordilleran margin. Earth-Science Reviews 136, 59-95.

YonKeE, W. A. \& WeIL, A. B. 2010. Reconstructing the kinematic evolution of curved mountain belts: Internal strain patterns in the Wyoming salient, Sevier thrust belt, 
USA. Geological Society of America Bulletin 122(1-2), 24-49.

YonkeE, W. A. \& WeIL, A. B. 2015. Tectonic evolution of the Sevier and Laramide belts within the North American Cordillera orogenic system. Earth-Science Reviews 150, 531-93.

Zandt, G., Myers, S. C. \& Wallace, T. C. 1995. Crust and mantle structure across the Basin and Range-Colorado Plateau boundary at $37 \mathrm{~N}$ latitude and implications for Cenozoic extensional mechanism. Journal of Geophysical Research: Solid Earth 100(B6), 10529-48.

ZIENKIEWICZ, O. C. \& TAYloR, R. L. 2005. The Finite Element Method for Solid and Structural Mechanics. Butterworth-Heinemann.

Figure 1. (Colour online) (a) Early Triassic location of the Sonoma Foreland Basin (SFB; after Brayard et al. 2013). (b) Simplified chronostratigraphy of the succession of structuring events in the studied area since Palaeoproterozoic time (after Oldow et al. 1989; Whitmeyer \& Karlstrom, 2007; Dickinson, 2013). (c) Simplified map of the study area with location of the main structural elements discussed and mentioned in this work (after Bond et al. 1985; Walker, 1985; Dickinson, 2004, 2006, 2013; Vetz, 2011; Yonkee \& Weil, 2015).

Figure 2. (Colour online) Topographic map of the central part of current-day Sevier thrustand-fold belt with accentuation of the Wyoming and Central Utah salients thrusts. A lateral ramp is present between the two salients (after Paulsen \& Marshak, 1999).

Figure 3. (Colour online) (a) Simplified litho- and chronostratigraphic subdivisions of the Early Triassic Sonoma Foreland Basin (SFB). This study encompasses the PTU-Smithian interval, with Spathian complement for the subsidence analysis. Main ammonoid markers used in this study are the Anasibirites beds and the Columbites beds. Radiometric ages: (1) from Burgess, Bowring \& Shen (2014); (2) and (3) from Galfetti et al. (2007). (b) State map of the study area showing current location of the 43 studied sections, from both literature data (open circles) and field data (grey circles). Complete GPS coordinates and references are given in online Supplementary Table S2. Red outlines highlight the sections used for the subsidence analysis, and selected for their completeness, temporal resolution and spatial distribution. Sections detailed in Figure 4: SC: Sheep Creek; HS: Hot Springs; LWC: Lower Weber Canyon; CR: Confusion Range; T: Torrey area; PR: Pahvant Range; M: Minersville; $\mathrm{RC}$ : Rock Canyon.

Figure 4. Biostratigraphic correlation based on the Anasibirites and Columbites beds observed in 8 of the 43 studied sections, illustrating the discrepancy in sedimentary thickness 
1086 between the southern and northern parts of the Sonoma Foreland Basin (with simplified 1087 lithology). Base of the sections corresponds to the regionally recognized Permian-Triassic 1088 unconformity (Brayard et al. 2013).

1089 Figure 5. (Colour online) Photographs of different outcrops in the SFB, showing variations in 1090 dominant lithologies and sedimentary thicknesses encountered throughout the basin. (a) 1091 Panorama of Rock Canyon (RC) outcrop, showing the plurimetric beds of conglomerates 1092 from the basal Moenkopi Group. (b) Detail photograph of the conglomerate from Rock 1093 Canyon. (c) Photograph of the terrigenous red beds of the Moenkopi Group at Lower Weber 1094 Canyon (LWC). (d) Panorama of the limestones beds of the Thaynes Group limestones at 1095 Lower Weber Canyon. (e) Panorama of the Moenkopi Group at Minersville (M), showing 1096 succession of terrigenous red beds and microbial limestones. (f) Panorama of the transition between Moenkopi and Thaynes Group showing succession of microbial limestones and bioclastic limestones at Minersville. (g) Photograph of the marine siltstones of the Dinwoody and Woodside Formation at Hot Springs (HS). (h) Panorama of the Hot Springs section, showing succession of limestone levels of the Thaynes Group bioclastic limestones.

1101

1102

1103

1104

1105

1106

1107

1108

1109

1110

1111

1112

1113

1114

1115

1116

1117

1118

1119

1120

Figure 6. (Colour online) Present-day and retrodeformed (for the PTU-Smithian interval) configurations for two regional cross-sections in the (a) northern and (b) southern parts of the Sonoma Foreland Basin, illustrating the method used for palinspastic reconstruction (after Groshong, 2006). Balanced cross-sections adapted from (a) Yonkee \& Weil (2010) and (b) DeCelles \& Coogan (2006) illustrate the retrodeformation process used to estimate the value of the tectonic transport, and therefore the approximate original location of the sections during the studied interval. Triassic series (highlighted layers) are used as the basis for the retrodeformation process and are horizontalized between the designated Pin and Loose lines (see text for details). The two cross-sections are located in Figure 7.

Figure 7. (Colour online) Map representing the present-day location of the studied sections (dots) and their reconstructed position (open circles) obtained after retrodeformation. Positions of balanced cross-sections (a) and (b) illustrated in Figure 6 are also indicated. The present-day Sevier Thrust-and-Fold Belt (TFB; after Yonkee et al. 2014) is the main structural element responsible for tectonic transport during post-Triassic times. Black arrows represent the retrodeformation values applied from the present-day location of the studied sections. Seven sectors of similar estimated tectonic transport are delimited by dashed lines (see Table 1). Sector 1: Sevier foreland; Sector 2: Wyoming salient, northern part; Sector 3: Wyoming salient, central part; Sector 4: Wyoming salient, southern part; Sector 5: Central Utah salient, northern part; Sector 6: Central Utah salient, southern part; Sector 7: Sevier hinterland. 
and southern Sonoma Foreland Basin. The studied sections are shown at their palaeolocation (Fig. 7). The reconstructed Golconda Allochthon Thrust Front during the PTU-Smithian studied interval is also indicated (modified from Dickinson, 2013; see also Fig. 12). The position of the wedge-top is based on variations in the sedimentary thicknesses and on geophysical data (Fig. 10).

Figure 9. (Colour online) Subsidence analysis results obtained for the PTU-Smithian interval and early Spathian time using 1D backstripping (Steckler \& Watts, 1978; Van Hinte, 1978; Allen \& Allen, 2005). Locations of sections are given in Figure 3b. Ages for the bottom and top boundaries of the Smithian are interpolated from ammonoid biozone durations (after Brühwiler et al. 2010). Sea-level curve after Haq, Hardenbol \& Vail (1988). Ana.: Anasibirites beds; Col.: Columbites beds. Radiometric ages from (1) Burgess, Bowring \& Shen (2014); (2) and (3) Galfetti et al. (2007). Subsidence analysis for: (a) Confusion Range (CR) section; (b) Pahvant Range (PR) section; (c) Sheep Creek (SC) section; (d) Hot Springs (HS) section. (e) Total subsidence curves for all the CR, PR, SC and HS sections and associated dominant lithologies are indicated for each subinterval. (f) Tectonic subsidence curves for the CR, PR, SC and HS sections and associated mean tectonic subsidence rates. (e) and (f) allow two distinct subsidence dynamics to be discriminated between the southern and northern parts of the SFB.

Figure 10. (Colour online) (a) Bouguer gravity anomaly map of the Sonoma Foreland Basin and its surroundings (in mGal; after Kucks, 1999). Notable moderate gravity anomalies are highlighted by a white contour. SRP: Snake River Plain; FA: Farmington Anomaly; SA: Southern Anomaly. Black lines represent the interpreted remnants of the main geophysical accidents, and limits between crustal features. (b) Aeromagnetic anomaly map of the Sonoma Foreland Basin and its surroundings (in nT; after Bankey et al. 2002). Black lines highlight areas of contrasted magnetic signatures: SRP: Snake River Plain; SZ: Southern magnetic Zone; CZ: Central magnetic Zone; NEZ: North-Eastern magnetic Zone; NZ: Northern magnetic Zone. (c) Map of the spatial location of the radiochronological ages (U/Pb ages) after: (1) Foster et al. 2006; (2) Fan et al. 2011; (3) Mueller et al. 2011; (4) Nelson, Hart \& Frost, 2011; (5) Strickland, Miller \& Wooden, 2011). Superimposed red dots indicate Mesoproterozoic metamorphism episodes (Mueller et al. 2011). (d) Map of basement terranes of the SFB according to their age and nature, with Archean terranes (pale blue), Palaeoproterozoic terranes (pale green) and Mesoproterozoic mobile belt (pale red). FT: Farmington Terrane; GCB: Grouse Creek Block; MT: Mojave Terrane; WT: Wyoming Terrane; YT: Yavapai Terrane.

Figure 11. (Colour online) Map of the SFB basement (cf. Fig. 10d) after their heritage and therefore their rheological behaviour. Archean Grouse Creek Block and Wyoming Terrane, Palaeoproterozoic Mojave Terrane and Yavapai Terrane are considered 'strong' lithospheres with an important rigidity (pale blue), while the Mesoproterozoic mobile belt Farmington 
1161

1162

1163

1164

1165

1166

1167

1168

1169

1170

1171

1172

1173

1174

1175

1176

1177

1178

1179

1180

1181

1182

1183

1184

1185

1186

1187

1188

1189

1190

1191

1192

1193

1194

1195

1196

1197

Terrane is considered a 'thermally attenuated weak' lithosphere due to its lesser rigidity (pale red).

Figure 12. (Colour online) (a) Simplified map showing the position of the Uinta recess (lateral ramp) and Wyoming and Central Utah salients (frontal ramps) of the present-day Sevier TFB (after Paulsen \& Marshak, 1999; Yonkee \& Weil, 2010) and reconstructed Golconda Allochthon front and associated recess (lateral ramp). Sedimentary pattern since Proterozoic time shows two high accommodation zones separated by a topographic high close to the terrane boundaries (Peterson, 1977, Bryant \& Nichols, 1988; Paulsen \& Marshak, 1999). Palaeolocation of Permian Oquirrh Basin (e.g. Yonkee \& Weil, 2015) and documented PTU-Smithian conglomerates in the western SFB (e.g. Gabrielse, Snyder \& Stewart, 1983; Lucas \& Orchard, 2007) are also included on the map. Red lines indicate limits of the basement terranes (cf. Fig 9d). (b) Photograph (courtesy of Hugo Bucher, Zürich) of the conglomerates found in the area delimited in (a), presumably a product of western relief dismantlement.

Figure 13. (Colour online) Numerical model of the SFB after the reconstructed palaeogeography and terranes map (cf. Figs 11,12) with an heterogeneous basement ('strong' v. 'thermally attenuated weak' lithospheres) and an heterogeneous allochthon (recessed area in central part of the front). (a) Simulated map of the SFB. Thin black lines indicate the position of the 2D profiles; red lines indicate limits of the basement terranes (cf. Fig 10d). (b) 2D W-E profile of the northern part of the SFB model. The narrow foredeep is emplaced upon the 'thermally attenuated weak' FT and is bordered by a well expressed forebulge. (c) 2D W-E profile of the southern part of the SFB model. The wider foredeep is emplaced upon the 'strong' MT, and is bordered by a barely expressed forebulge. (d) 2D N-S profile of the SFB model. The two northern and southern parts of the basin are individualized with a limit near the MT/FT boundary.

Figure 14. (Colour online) Numerical models showing the effects of the heterogeneities of the basement and of the topographic load over the formation of a foreland basin. Dashed lines represent an area analogue to the SFB configuration. (a) Scenario using a heterogeneous basement with contrasted elastic thicknesses $\left(T_{\mathrm{e} 1}=3 \times T_{\mathrm{e} 2}\right)$ and a homogeneous allochthon. A large convex foreland is formed upon the most rigid lithosphere. (b) Scenario using a heterogenous allochthon with a c. $100<5>\mathrm{km}$ wide recess (lateral ramp) and a homogeneous fixed $T_{\mathrm{e}}$ lithosphere. A slightly wider concave foreland is formed within the recessed area and a cornering relief appears on both sides of the recessed area in the allochthon. (c) Scenario showing the combined effect of a heterogeneous basement with contrasted elastic thicknesses $\left(T_{\mathrm{e} 1}=3 \times T_{\mathrm{e} 2}\right)$ and a heterogeneous allochthon with a $c .100<5>\mathrm{km}$ wide recess (lateral ramp). A much wider convex foreland is formed within the recessed area upon the rigid lithosphere, and a cornering relief on both sides of the recess in the allochthon is also visible. 
1198 Figure 15. (Colour online) Cross-sections of the Sonoma Foreland Basin (SFB) illustrating 1199 variations in the subsidence and sedimentary accumulation pattern during the PTU-Smithian 1200 interval. The Golconda Allochthon (GA) is the main topographic load on the lithosphere 1201 (Dickinson, 2006, 2013; Marzolf, 1993); the postulated wedge-top is also represented. ( $A A^{\prime}$ ) 1202 W-E cross-section in the northern part of the basin exhibiting a narrow foreland with a high1203 rate tectonic subsidence with a developed silty and limestone sedimentation over the 1204 Mesoproterozoic ‘thermally attenuated weak' Farmington Terrane (FT). (BB') W-E cross1205 section in the southern part of the Sonoma Foreland Basin showing a wide foreland with a 1206 low-rate tectonic subsidence, forming a reduced deposition of mainly terrigenous clastic 1207 series upon the Palaeoproterozoic 'strong' Mojave Terrane (MT). A barely expressed 1208 forebulge borders this part of the SFB. $\left(C C^{\prime}\right.$ '). N-S cross-section of the basin, highlighting the 1209 differences between southern and northern parts of the SFB in terms of subsidence, 1210 sedimentation and geometry of the basin. The transition between these two parts is situated 1211 close to the terranes boundary between MT and FT. This area is postulated to be a basement 1212 topographic highland, as supported by the transition between southern terrigenous clastic 1213 series and northern silty sedimentation. 

sectors defined within the SFB, and associated references.

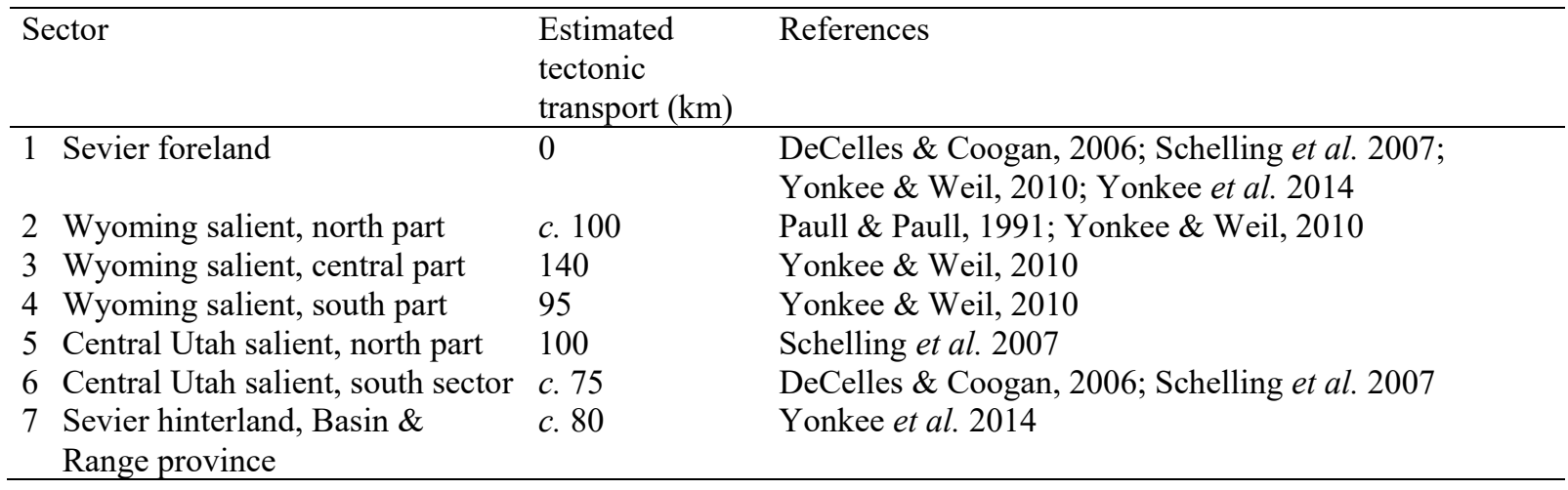

1217 Table 2. Summary of model parameters for the SFB and tested scenarii.

\begin{tabular}{|c|c|c|c|c|}
\hline Parameter & $\begin{array}{l}\text { SFB model } \\
\text { (Fig. 13) }\end{array}$ & $\begin{array}{l}\text { Heterogeneous } \\
\text { basement } \\
\text { scenario } \\
\text { (Fig. 14a) }\end{array}$ & $\begin{array}{l}\text { Heterogeneous } \\
\text { allochthon } \\
\text { scenario } \\
\text { (Fig. 14b) }\end{array}$ & $\begin{array}{l}\text { Combined } \\
\text { heterogeneities } \\
\text { (basement \& } \\
\text { allochthon; } \\
\text { Fig. 14c) }\end{array}$ \\
\hline Young's modulus $E(\mathrm{GPa})$ & 80 & 80 & 80 & 80 \\
\hline Poisson's ratio, $v$ & 0.25 & 0.25 & 0.25 & 0.25 \\
\hline $\begin{array}{l}\text { Elastic thickness of 'strong' lithosphere, } T_{\mathrm{e} 1} \\
(\mathrm{~km})\end{array}$ & 90 & 90 & 90 & 90 \\
\hline $\begin{array}{l}\text { Elastic thickness of 'weak' lithosphere, } T_{\mathrm{e} 2} \\
(\mathrm{~km})\end{array}$ & 30 & 30 & $\mathrm{n} / \mathrm{a}$ & 30 \\
\hline \multicolumn{5}{|l|}{ Loading parameters } \\
\hline Allochthon thickening, $h(\mathrm{~m})$ & 1500 & 1500 & 1500 & 1500 \\
\hline Density of topographic load, $\rho_{\mathrm{t}}\left(\mathrm{kg} \mathrm{m}^{-3}\right)$ & 2700 & 2700 & 2700 & 2700 \\
\hline Density of the mantle, $\rho_{\mathrm{m}}\left(\mathrm{kg} \mathrm{m}^{-3}\right)$ & 3300 & 3300 & 3300 & 3300 \\
\hline Density of the sedimentary infill, $\rho_{\mathrm{i}}\left(\mathrm{kg} \mathrm{m}^{-3}\right)$ & 1600 & 1600 & 1600 & 1600 \\
\hline Gravitational acceleration, $g\left(\mathrm{~m} \mathrm{~s}^{-2}\right)$ & 9.81 & 9.81 & 9.81 & 9.81 \\
\hline
\end{tabular}




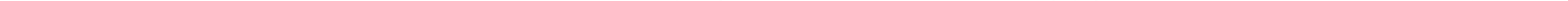


W113

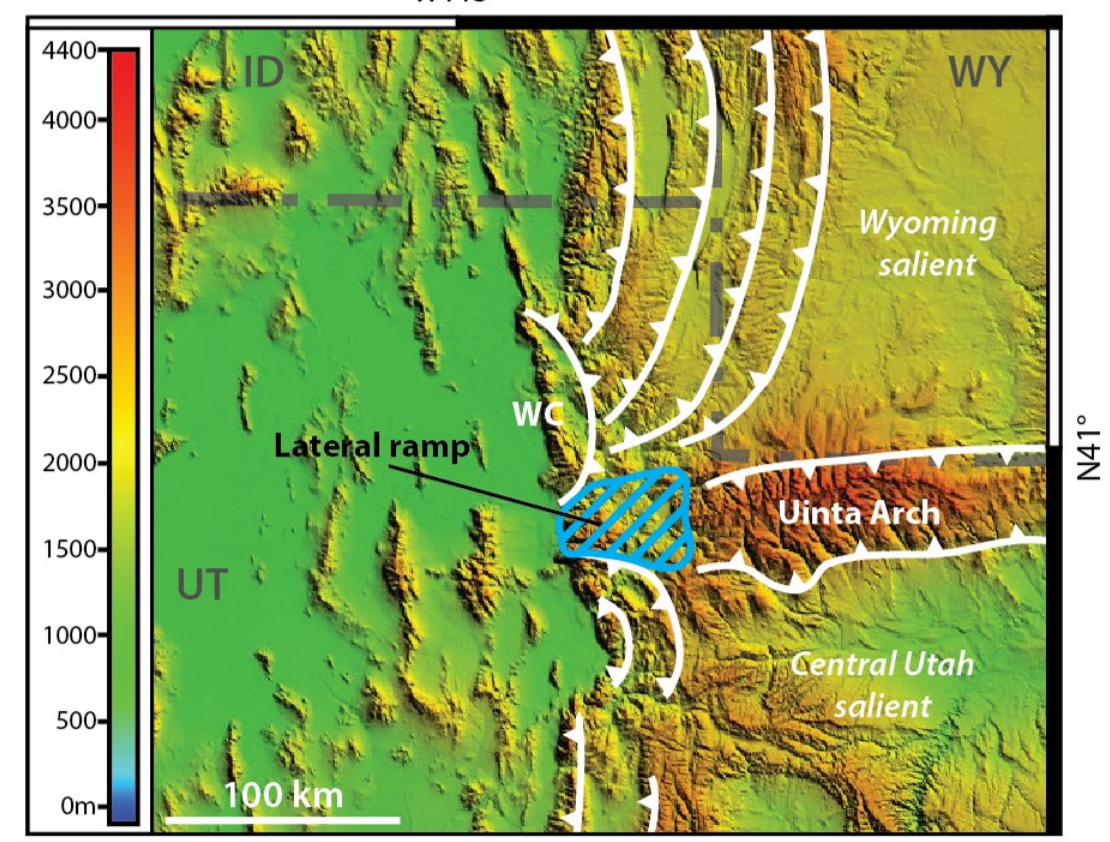




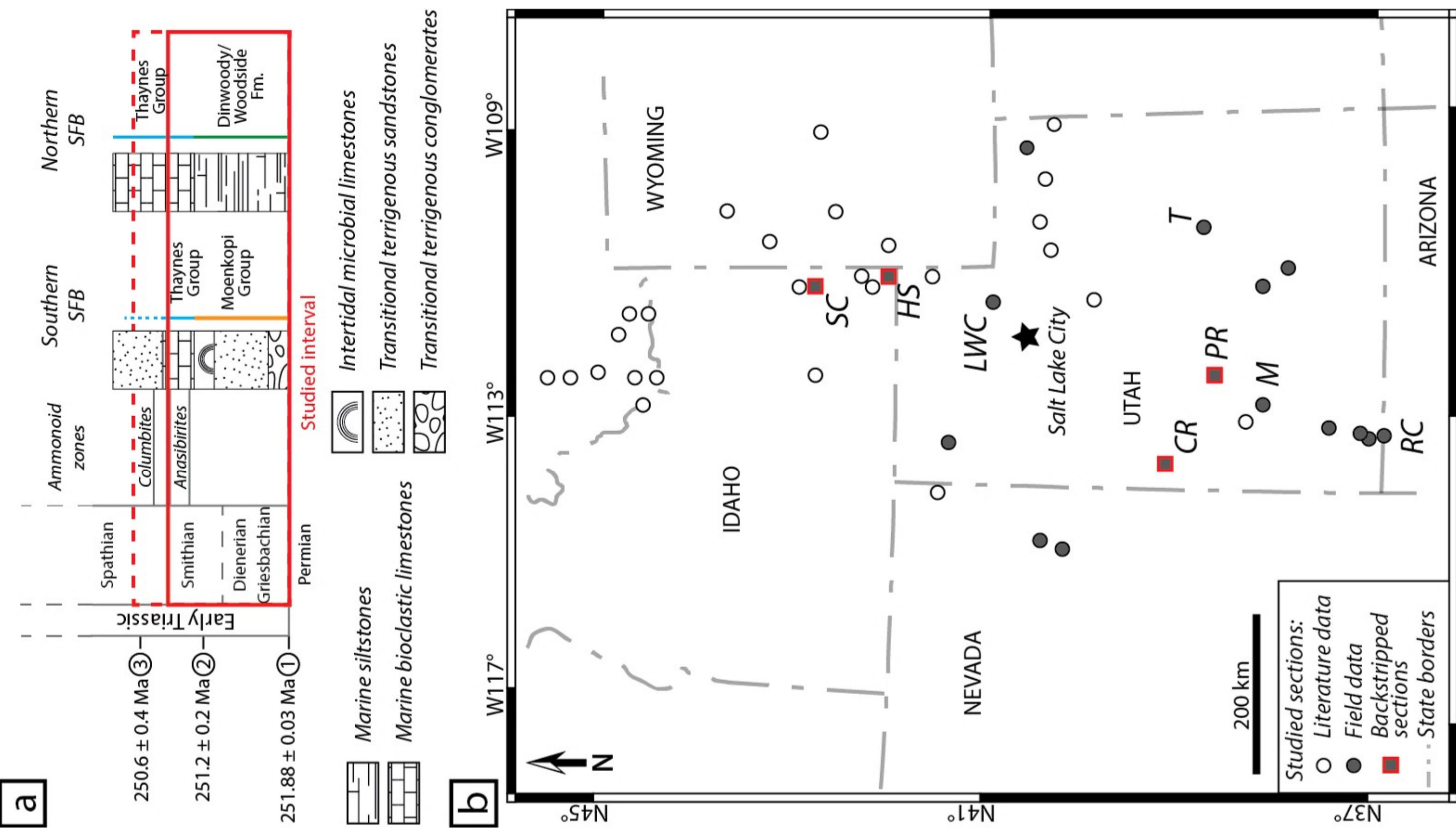




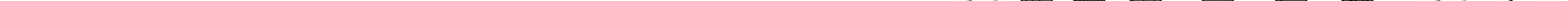




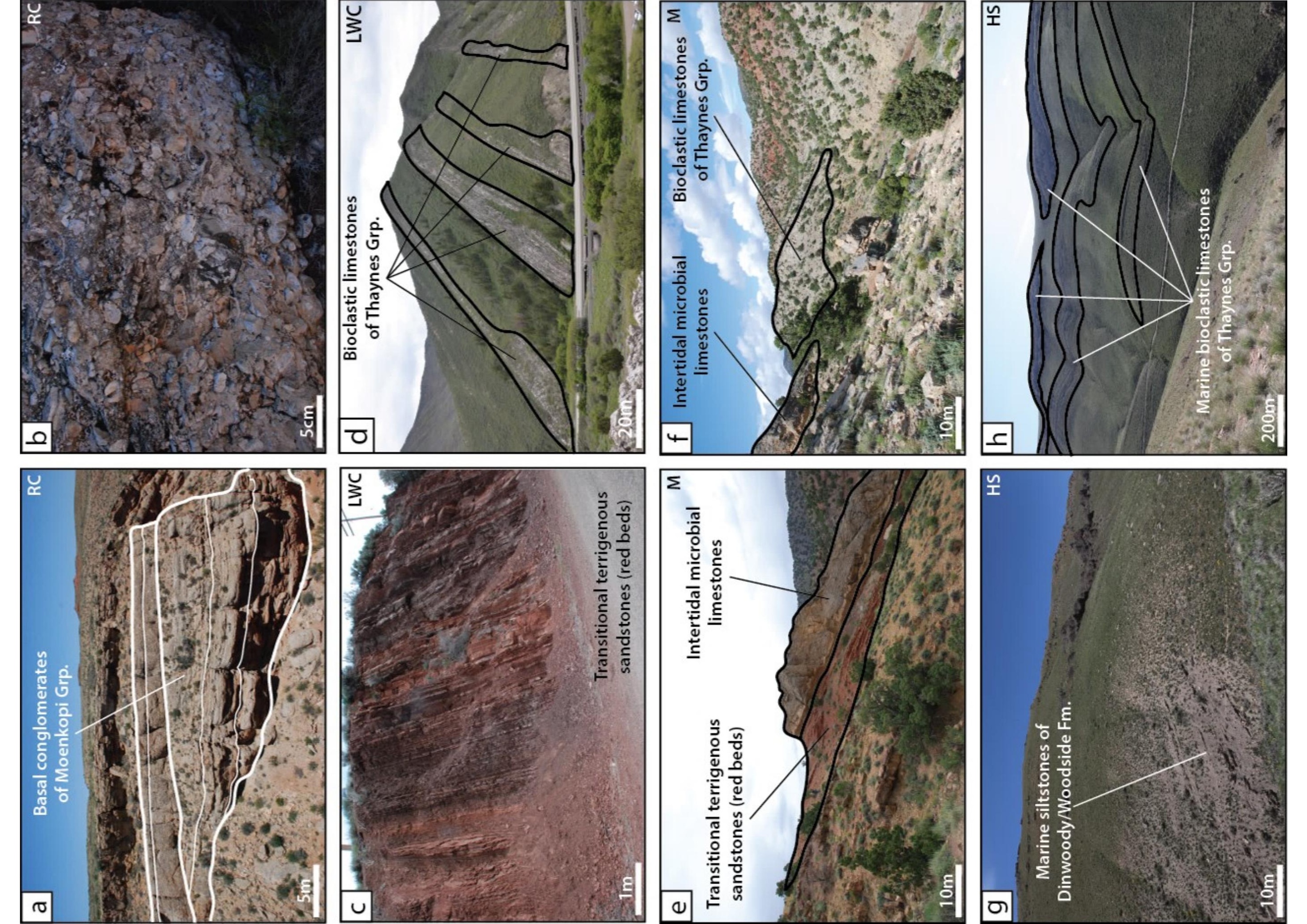




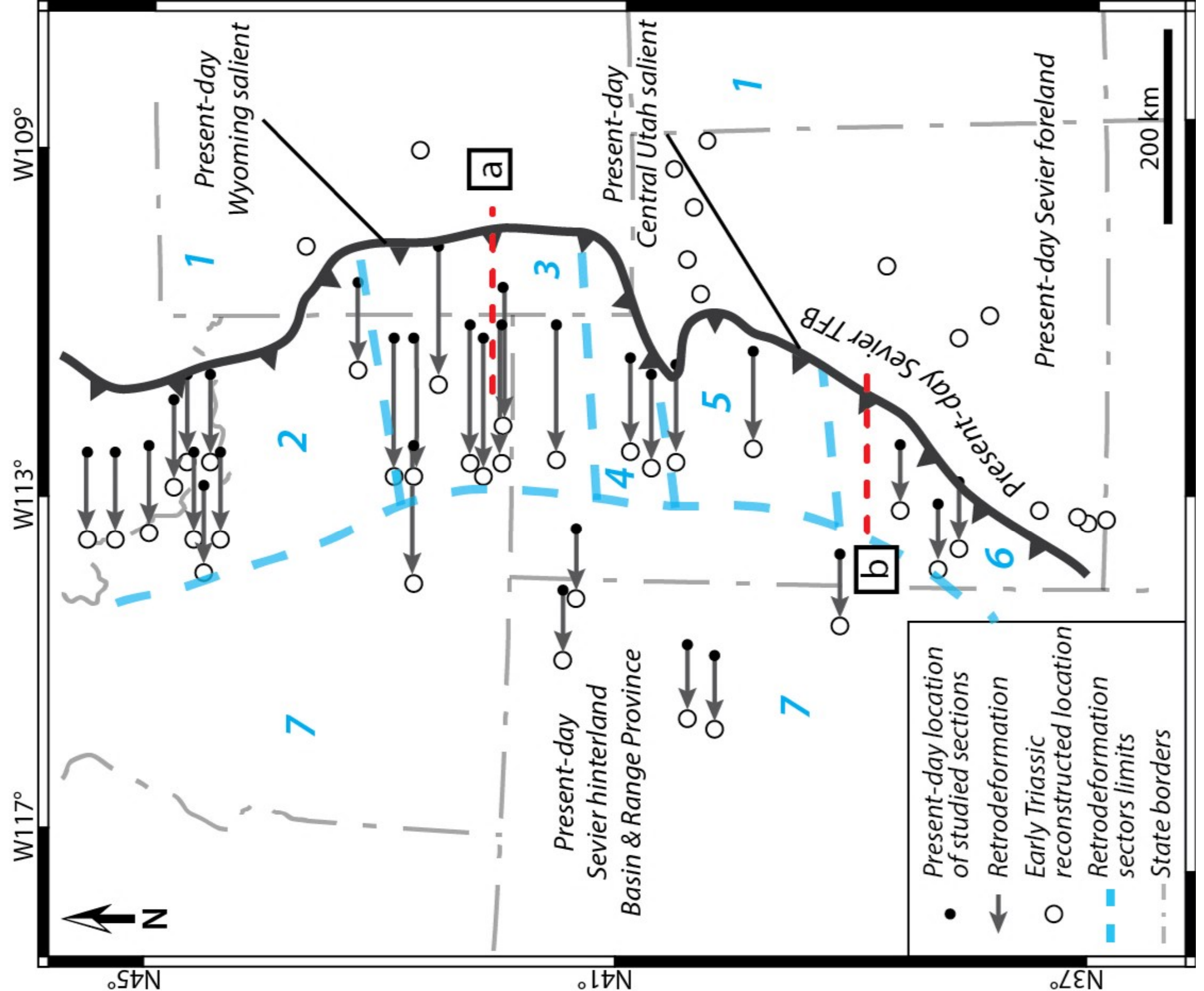




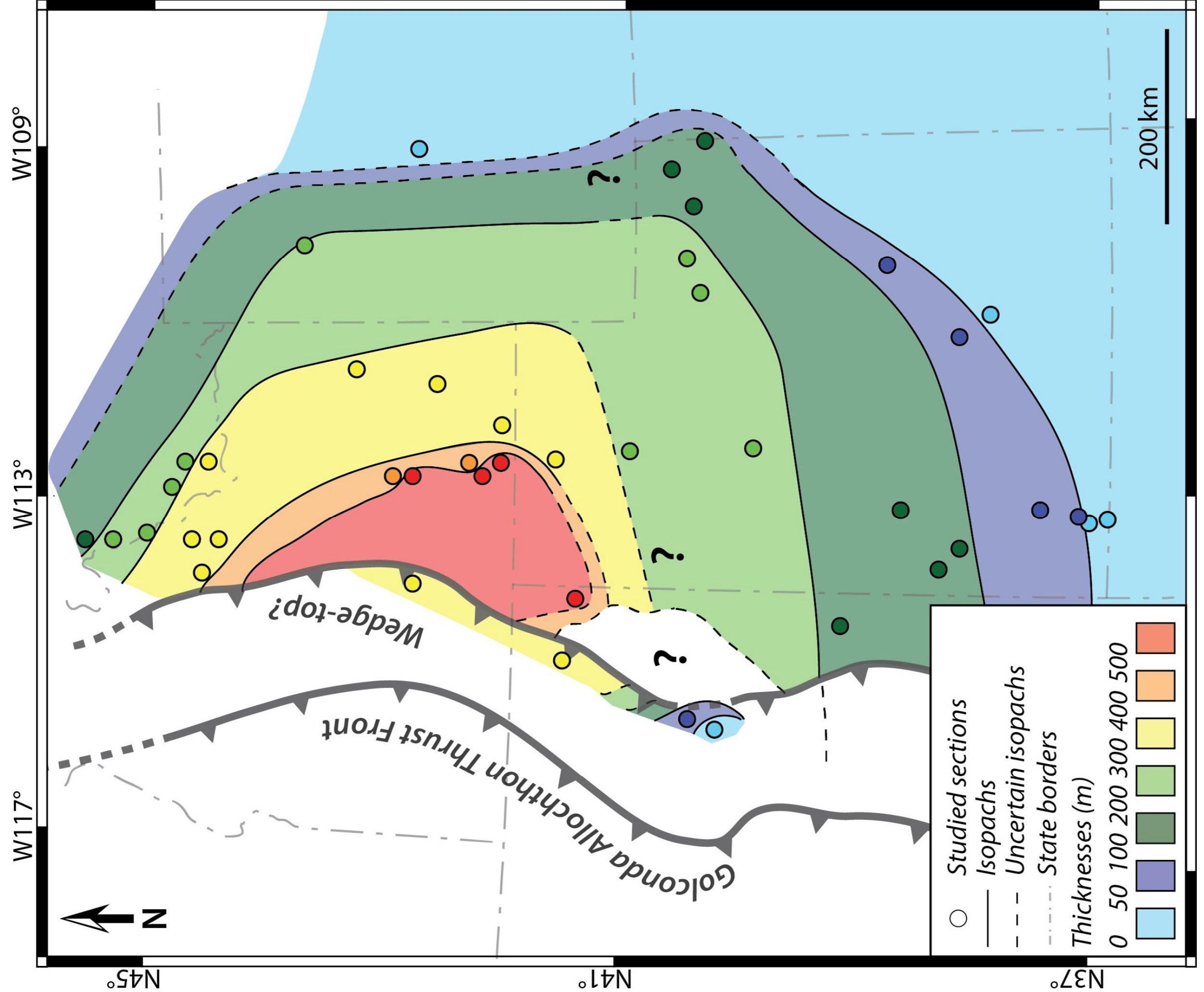




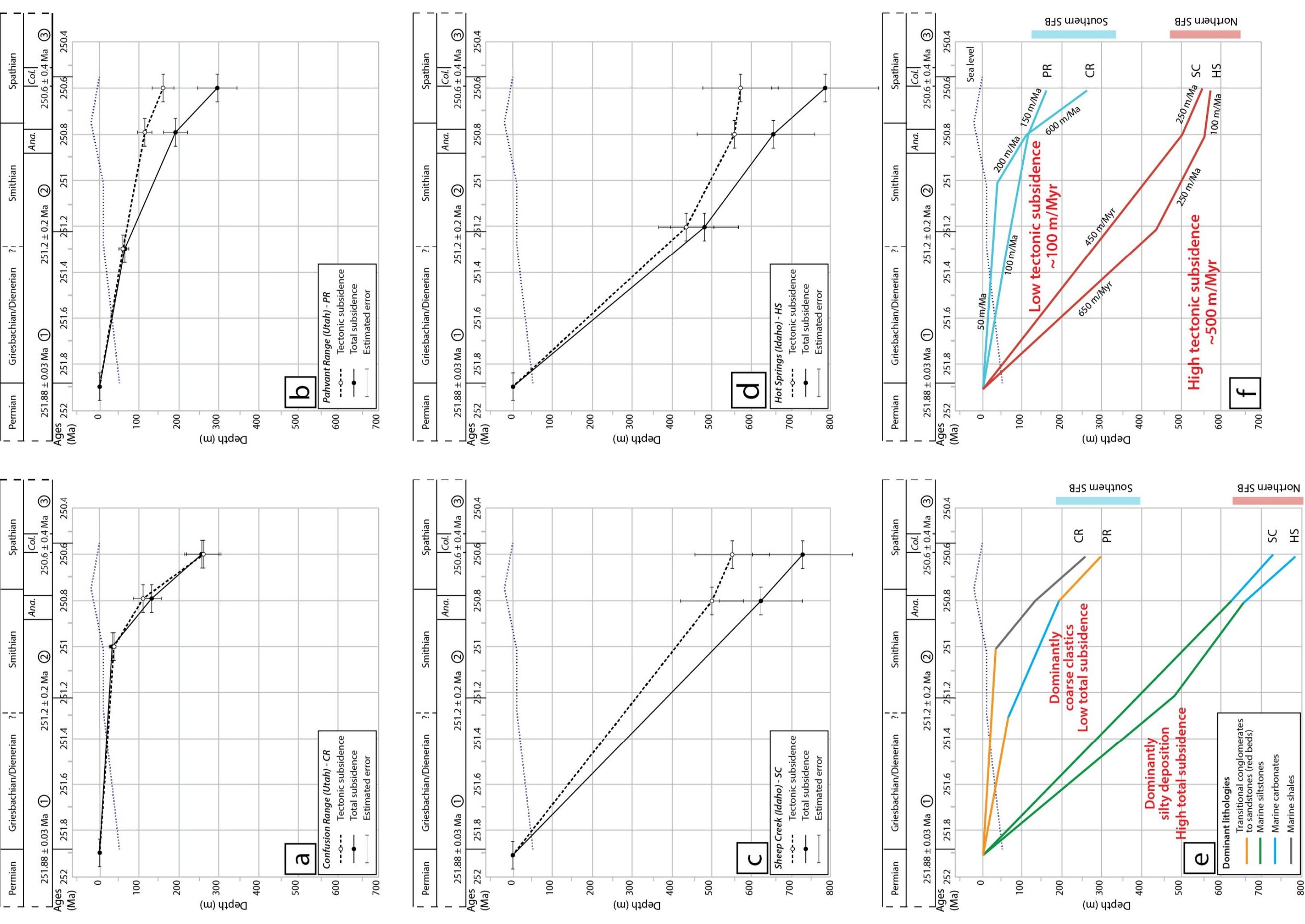



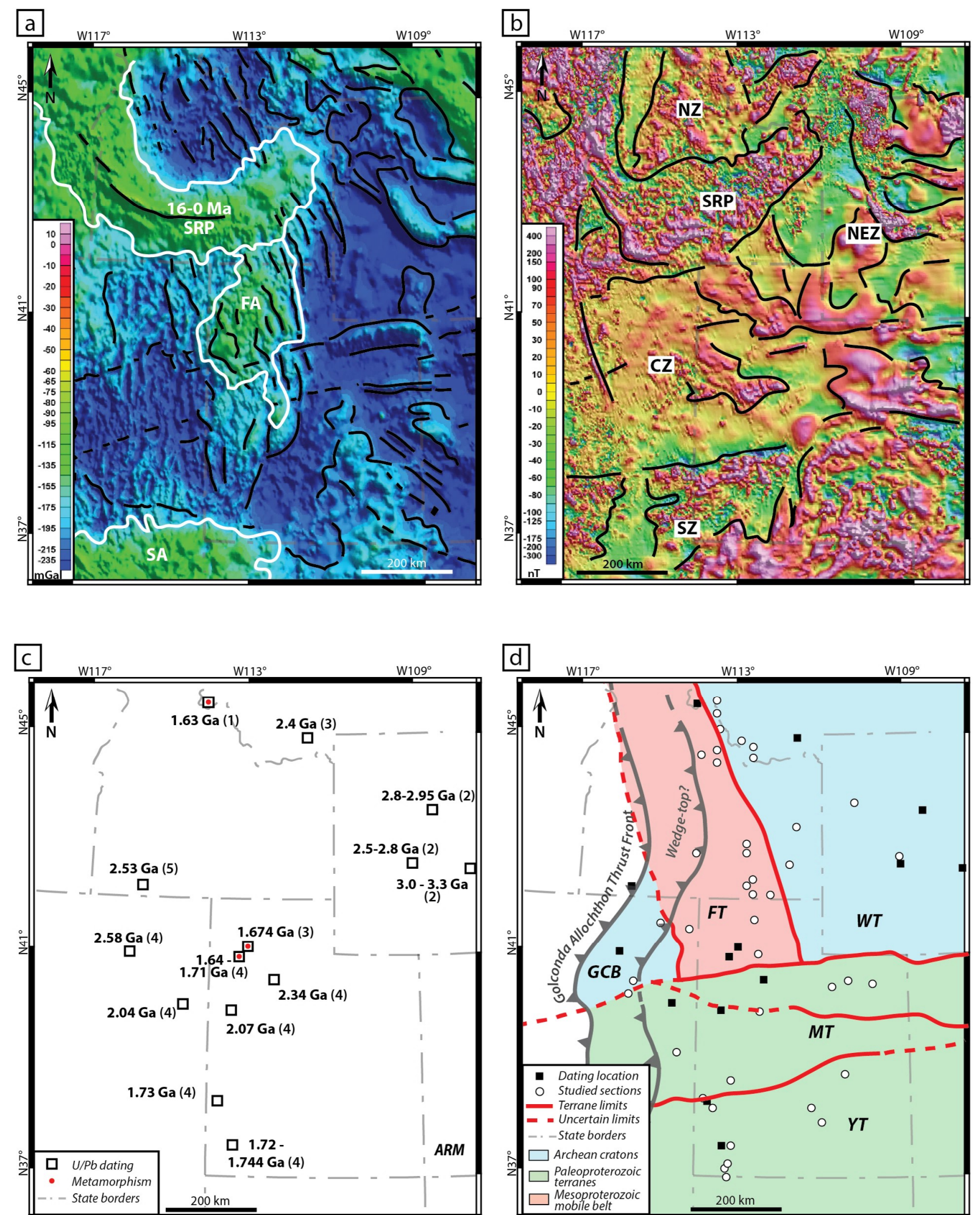


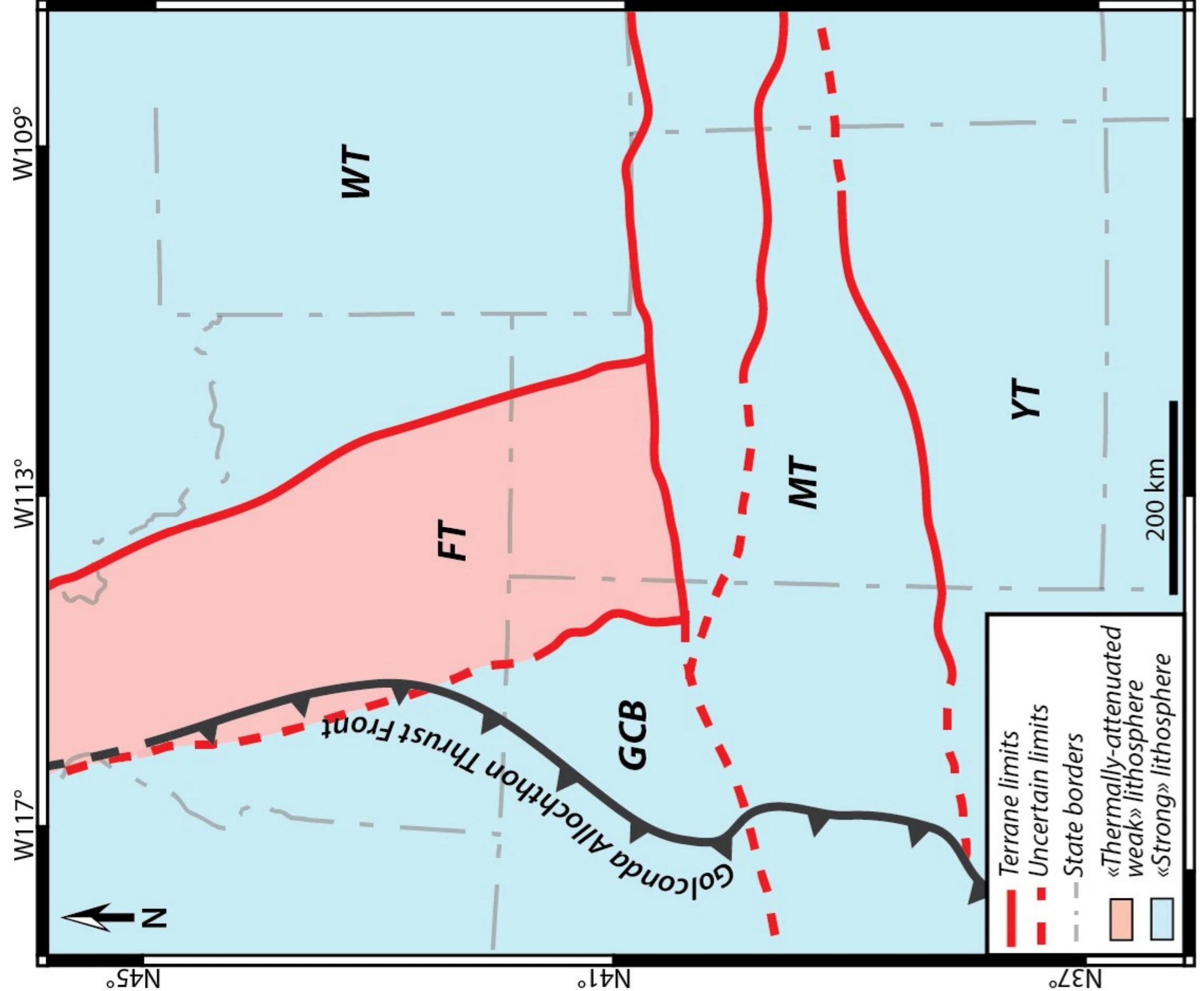



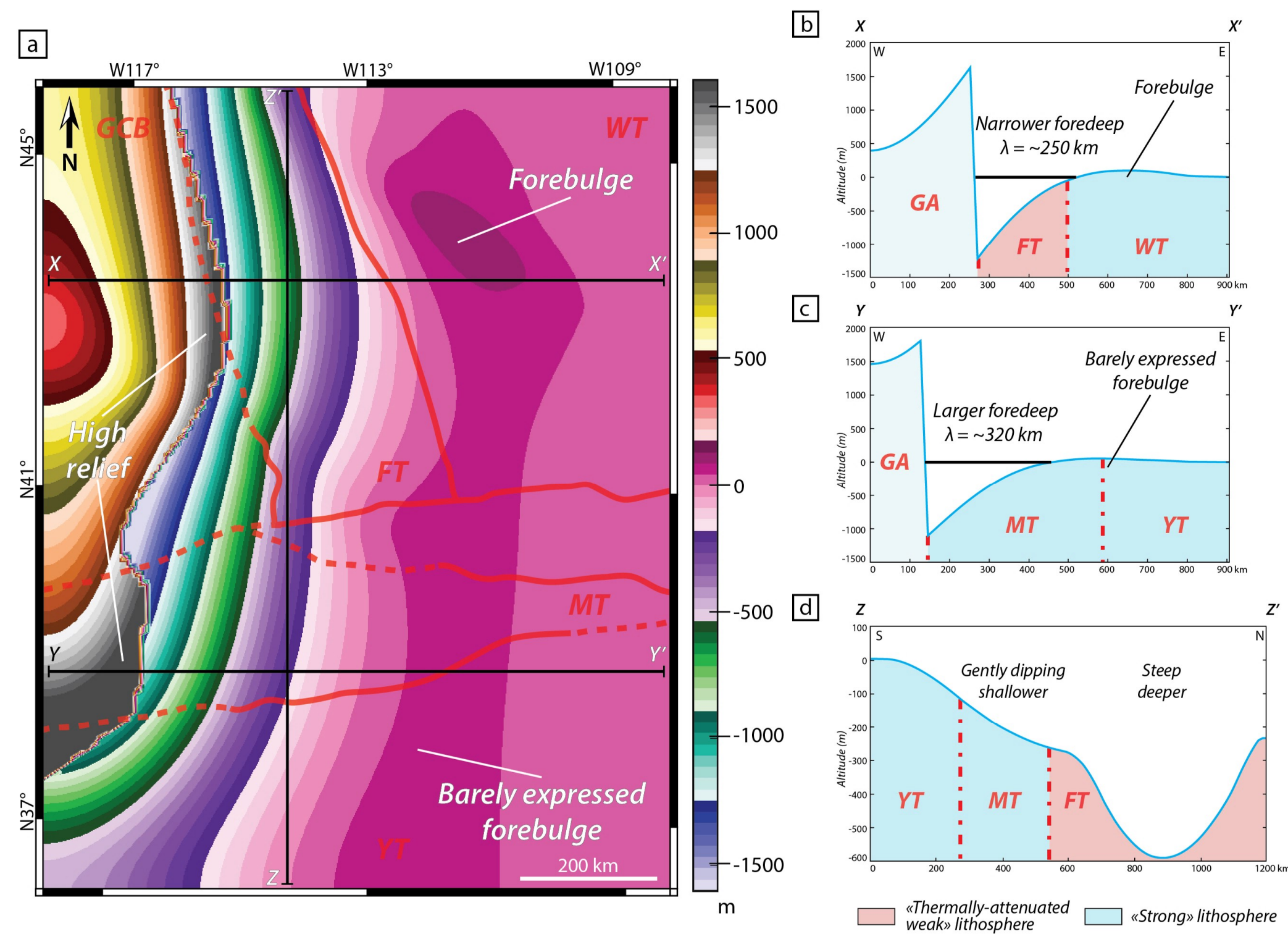


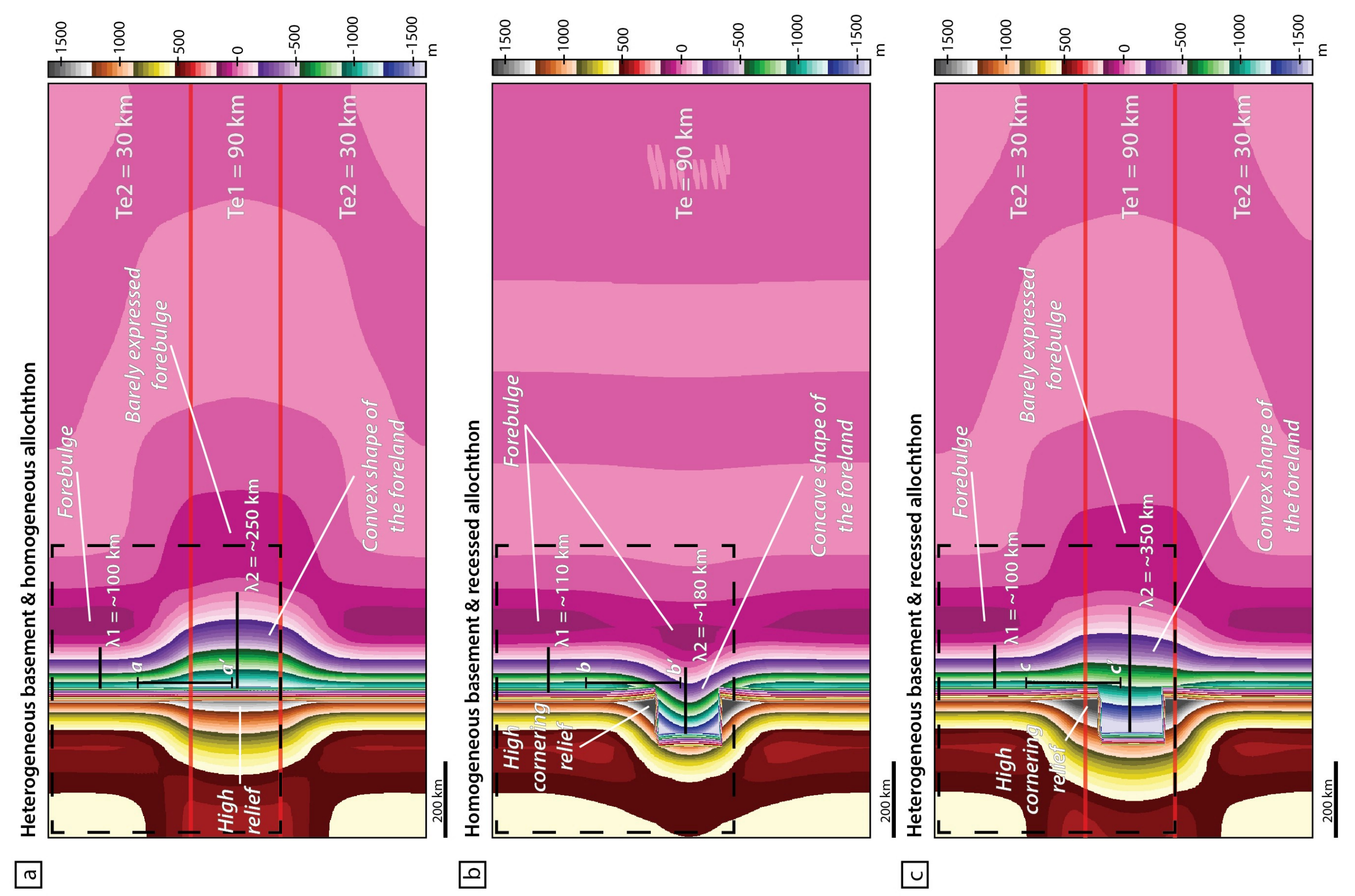


Golconda Allochthon 'Wedge- Foredeep I Forebulge
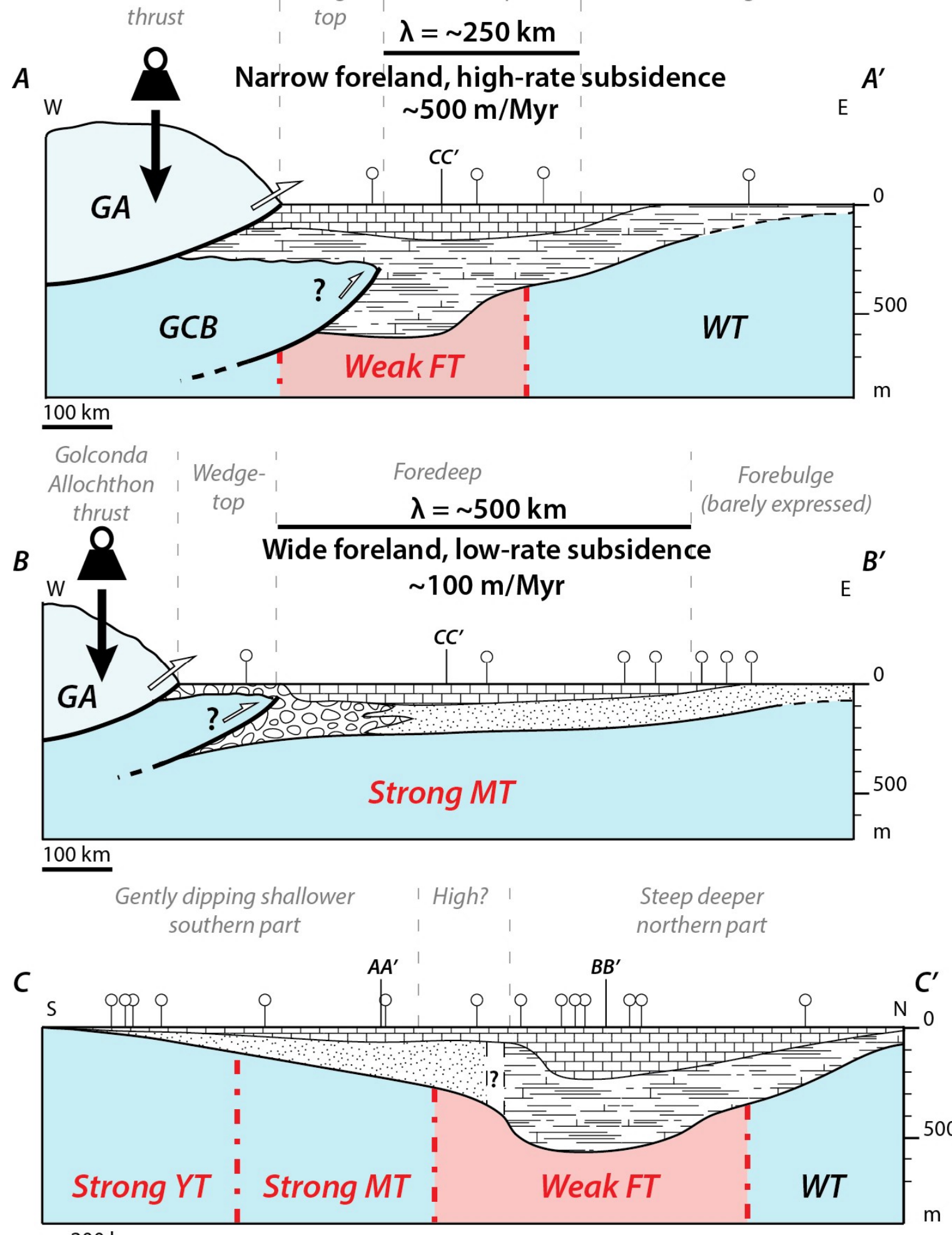

$200 \mathrm{~km}$
SFB basement rheology

$\square$ «Strong» lithosphere «Thermally-attenuated weak» lithosphere

PTU-Smithian sediments dominant lithologies

\section{I-A Marine siltstones}

폴 Marine bioclastic limestones

Transitional terrigenous sandstones

Transitional terrigenous conglomerates

$\longrightarrow$ Thrusting

o Golconda Allochthon

topographic load

Studied sections (see Figs. 3-8)

ـ._ Golconda Allochthon thrust front

$\triangle \wedge \wedge$ Postulated wedge-top

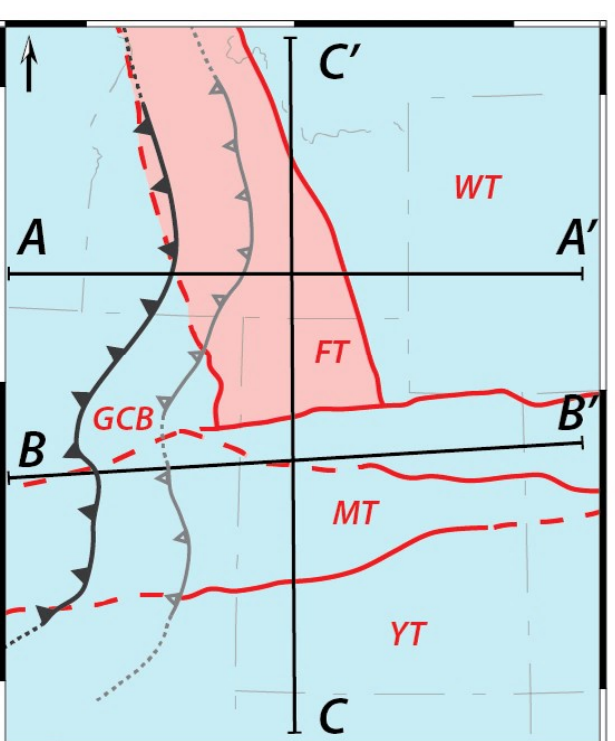

